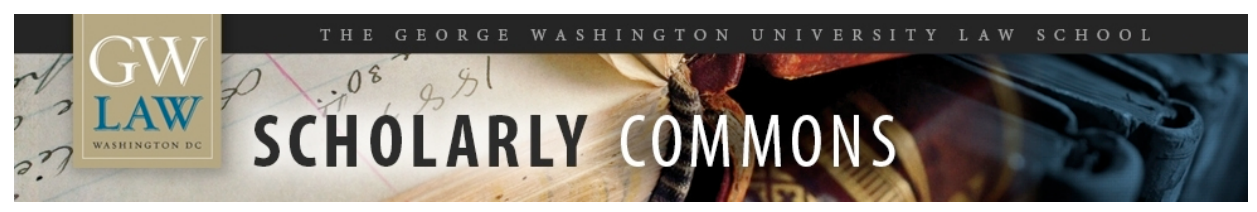

\title{
"The Evolution of Employment Discrimination Law: Changed Doctrine for Changed Social Conditions "
}

\author{
Michael Selmi \\ George Washington University Law School, mselmi@law.gwu.edu
}

Follow this and additional works at: https://scholarship.law.gwu.edu/faculty_publications

Part of the Law Commons

\section{Recommended Citation}

Selmi, Michael, "'The Evolution of Employment Discrimination Law: Changed Doctrine for Changed Social Conditions "'" (2014). GW Law Faculty Publications \& Other Works. 1110.

https://scholarship.law.gwu.edu/faculty_publications/1110

This Article is brought to you for free and open access by the Faculty Scholarship at Scholarly Commons. It has been accepted for inclusion in GW Law Faculty Publications \& Other Works by an authorized administrator of Scholarly Commons. For more information, please contact spagel@law.gwu.edu. 


\title{
The Evolution of Employment Discrimination Law: Changed Doctrine for Changed Social Conditions
}

\author{
Michael Selmi*
}

\section{INTRODUCTION}

Times change, and often, when they do, the law must change as well. This is an issue that has typically been overlooked in our legal system, a system that is based on precedent with limited means for adjusting that precedent and no clear avenue for judicial updating of the law. Courts typically overturn or distinguish precedent, they may even modify it, but they rarely declare that prior law no longer fits current conditions. In other words, a Court rarely proclaims something to the effect of, "That was then, this is now." Rather, when statutes become outdated courts often wait for Congress to alter the statute rather than changing past precedent to conform to the changed conditions. ${ }^{1}$

Employment discrimination law has long been ripe for updating. Many of the core cases regarding how discrimination is defined and proved arose in the 1970s in a very different era and were designed to address very different kinds of discrimination. Those early cases came on the heels of the Civil Rights movement, when overt discrimination and segregated workforces were the norm, and when men and women were routinely considered to have different abilities and interests. Equally clear, those early cases invariably dealt with the remnants of overt segregation. To take a prime example, the well-known disparate impact case of Griggs v. Duke Power Company involved employment practices that were adopted the day

\footnotetext{
* Samuel Tyler Research Professor, George Washington University Law School. Versions of this paper have been presented at a number of conferences and law school workshops where I have received valuable comments. I am particularly indebted to the comments and conversations of Sam Bagenstos, Donald Braman, Roberto Corrado, Melissa Hart, Deborah Hellman, Rona Kitchen, Maria Ontiveros, Wendy Parker, George Rutherglen, Vicki Schultz, Charlie Sullivan, and many others. I have also benefitted by the research assistance of Michelle O’Meara and Sylvia Tsakos.

1 One area where the Court has been moving to adjust a statute to contemporary conditions is with the Voting Rights Act, where the Supreme Court recently invalidated a requirement that certain jurisdictions with a detailed history of discrimination had to seek federal government approval for voting rights changes See Shelby County v. Holder, 133 S.Ct. 2612 (2013). An important part of the Court's determination was that the rules that governed jurisdictions based on discrimination from the 1960s and 1970s no longer had the same relevancy. See id. at 2625 (noting that "Nearly 50 years [after Voting Rights Act was passed], things have changed dramatically" and proceeding to document those changes).
} 
the 1964 Civil Rights Act became effective by an employer that had previously confined African Americans to its least desirable jobs. ${ }^{2}$ Yet, the law that was established in Griggs remains, with slight modifications, the same today even though the conditions that motivated the Court to create the disparate impact cause of action have clearly changed. ${ }^{3}$ In light of the progress our society has made, one can reasonably ask whether a practice that is facially neutral but has discriminatory effects should be treated as discrimination today, whether the justification for doing so remains the same today as it was forty years ago. The answer to that question may very well be yes but neither Congress nor the Court has had an open discussion regarding the relevance of the disparate impact theory for contemporary society, though as will be discussed in detail below, the Supreme Court has recently and implicitly answered the question in the negative.

Indeed, over the last few years the Supreme Court has taken notice of the way social conditions have changed and it has begun a deliberate, but unannounced, revamping of existing case law. During this time period, the Supreme Court has decided four important employment discrimination cases that all resembled claims from an earlier era and it has decidedly rejected the old models of proof and has done so without overturning a single case. ${ }^{4}$ In each of the recent cases, the Supreme Court has rejected some of the earlier doctrine, whether that has to do with the relevance of the disparate impact theory, the power of rudimentary statistical analysis to establish class claims of intentional discrimination, or the fear of retaliation that might prevent someone from complaining, but it has done so without directly confronting the ill-fit between the aged case law and the changing nature of discrimination. With one important exception, Congress has remained on the sidelines in this deliberate doctrinal transformation. ${ }^{5}$

Discrimination law is different from other areas of the law such as

2401 U.S. 424 (1971).

3 Today the disparate impact section is codified as part of Title VII, and the statutory standards are quite similar to what was originally established in the Griggs case and later amplified by a second case, Albemarle Paper Co. v. Moody, 422 U.S. 405 (1975). The statutory provision was added as part of the Civil Rights Act of 1991 and can be found at 42 U.S.C. § 2000e-2(k).

4 The four cases are Ledbetter v. Goodyear Tire \& Rubber Co., 550 U.S. 618 (2007); AT\&T v. Hulteen, 556 U.S. 701 (2009); Ricci v. DeStefano, 557 U.S. 557 (2009) and Wal-Mart Stores, Inc. v. Dukes, 131 S.Ct. 2451 (2011).

5 The exception was the passage of the Lilly Ledbetter Fair Pay Act of 2009, which repudiated the Supreme Court's Ledbetter decision. See Lilly Ledbetter Fair Pay Act of 2009, Pub. L. No. 111-2, 123 Stat. 5 (codified as mended 42 U.S.C. § 200e \& 29 U.S.C. § 626, 2001). 
contracts or torts, or even constitutional law in that there has long been an assumption that one purpose of the Civil Rights laws was to substantially reduce the amount of discrimination that exists in our society. The law was designed to do more than just resolve inevitable disputes; the law was intended to alter social conditions, and once that purpose was satisfied, the law would need to adapt to the new situation. Most scholars in the area, myself included, firmly believe that the purpose of reducing discrimination has not yet been fully realized but it would be difficult to contend that the prevalence of discrimination has not receded. This is one issue on which many liberal commentators have been less influential than they might have otherwise been because their work can be interpreted to suggest that discrimination has not receded but, in fact, has become even more pervasive. $^{6}$ Yet, in charting a future doctrinal path, it is crucial to acknowledge the dramatic decrease in discrimination from the early years of antidiscrimination law, and the real question for courts and commentators is how the changing nature and extent of discrimination should be reflected in contemporary antidiscrimination law.

The Supreme Court's answer to this question has been wholly unsatisfactory. The Court has largely rejected the continuing relevance of the disparate impact doctrine and statistical proof of discrimination, presumably under the notion that neither is relevant to contemporary discrimination. While it may have made sense to look at an employer's workforce in the 1970s and proclaim that the underrepresentation of women or minorities was the product of discrimination, that conclusion no longer holds force. Today when the Supreme Court looks at an imbalanced workforce, like the one that was at issue in the recent Wal-Mart class action litigation, it is likely to shrug its shoulders before proclaiming that it does not know what accounts for the composition of the workforce. ${ }^{7}$

6 Among legal scholarships, there are two groups who seem to emphasize that discrimination has changed rather than receded. One group concentrates on the institutional nature of discrimination, the way in which discrimination seeps into organizations or societies. See, e.g., Ian Haney Lopez, Intentional Blindness, 87 N.Y.U. L. REV. 1779 (2012); Tristin Green, A Structural Approach to Andiscrimination Mandate: Locating Employer Wrong, 60 VANDERBILT L. REV. 849 (2007); Trristin Green, Discrimination in Workplace Dynamics: Toward a Structural Account of Disparate Treatment Theory, 38 HARVARD CiV. Rights - CiV. LiB. L. REV. 91 (2003). The other group are those scholars who tout the importance of the Implicit Association Test as an indicator of discrimination. See, e.g., Robert J. Smith \& Justin D. Levinson, The Impact of Implicit Racial Bias on the Exercise of Prosecutorial Discretion, 35 SEATTLE L. REV. 795 (2012); Jerry Kang \& Kristin Lane, Seeing Through Colorblindness, 58 UCLA L. REV. 465 (2010). The issue of implicit bias is taken up in section IV.A, and I will discuss the institutional discrimination thesis (much of which I agree with) in section IV.B.2.

7 See Wal-Mart Stores, Inc. v. Dukes, 131 S.Ct. 2451 (2011), discussed infra at 
Discrimination is no longer seen as the default explanation. In a similar vein, when employees come to the Court to complain about the continuing effects of discrimination that occurred many years earlier, the Court is likely to be entirely dismissive of the notion that there is any need for remedial action and it is more likely to criticize employees for not complaining sooner. ${ }^{8}$ And when employees complain about the disparate effects of examination results, the Court is more likely to see those results as the product of merit rather than discrimination. ${ }^{9}$

This, however, is not the unsatisfactory part of the doctrine, indeed, I believe the Court is largely correct to conclude that the kind of proof, or actions, that constituted discrimination forty years ago no longer have broad application to claims of contemporary discrimination. What is disturbing about the Court's recent decisions is what it has left in its wake. Although it is certainly true that discrimination has sharply receded since the 1970 s, it is also true that the discrimination that remains has changed in character, becoming more subtle, more entrenched, and more systemic in nature, which in turn means more difficult to identify or prove. This has been the unequivocal message of virtually all of the research conducted over the last two decades in a variety of fields and is also a common mantra among those who delve into the complexity of contemporary discrimination, including on occasion, the Supreme Court. ${ }^{10}$ Yet, the Court has not modified the case law to take into account the changed nature of discrimination but instead remains tied to doctrinal methods of proof that largely fail to capture more subtle forms of discrimination. The primary message arising out of the Supreme Court is that discrimination has receded not that it has changed. And while the Court is shedding some of its older doctrines, it remains

section III.D.

${ }^{8}$ See Ledbetter v. Goodyear Tire \& Rubber Co., 550 U.S. 618 (2007), discussed infra at section III.A.

${ }^{9}$ See Ricci v. DeStefano, 557 U.S. 557 (2009), discussed infra section III.C.

10 For a sampling of important work in this area see IAN AYRES, PERVASIVE PREJUdice? UnCONVENTIONAL EVIDENCE OF RACE AND GENDER DisCRIMINATION (2001); Nancy DiTomaso, The American Non-Dilemma: Racial InEQuality Without RACISM (2013); GLENN LOURY, THE ANATOMY OF RACIAL INEQUALITY (2002); CECILIA RIDGeWAy, Framed by GeNDER: HOW GENDER INEQUALITY PERSISTS IN THE MODERN World (2011); Virginia Valian, Why So Slow? The AdVANCEMENT of Women (1998); John F. Dovidio, On the Nature of Contemporary Prejudice: The Third Wave, 57 J. SOC. IsSUES 829 (2001). It bears emphasizing that the changed nature of discrimination is not a new concept. See, e.g., John F. Dovidio \& Samuel L. Gaertner, eds., PrEJUDICE, DISCRIMINATION AND RACISM (1986) (discussing new theories of discrimination including modern and aversive racism). The Supreme Court has been most attentive to issues of subtle discrimination in the area of criminal law. See, e.g., Snyder v. Louisiana, 552 U.S. 472 (2005) (rejecting as implausible a race-neutral explanation for striking juror). 
mired in a limited and old-fashioned mindset when it comes to identifying or defining discrimination, a mindset that continues to see discrimination as the product of isolated and aberrational bad actors. We are thus left with a large gap between what we know about contemporary discrimination and the ability of antidiscrimination law to identify that discrimination, and in the Court's view, reducing discrimination further will primarily occur as a result of the self-interests of employers.

This article will proceed as follows. The next section will detail the evolution of the doctrine in the 1970s and explain how most of the doctrine arose from cases of easily identifiable and overt exclusions. From there, I focus on four recent Supreme Court decisions to demonstrate the Court's rejection of the past doctrine, particularly with respect to recent cases seeking to challenge systemic discrimination. Those cases all could have emerged straight from central casting in the 1970s and the Court's recent decisions indicate that what constituted discrimination in that earlier era will may no longer be seen as discrimination today. Section IV turns to an exploration of how discrimination has changed, how it has become more subtle and complex over time, and also how the Supreme Court has, or more specifically, has not adapted to the evolving nature of discrimination. This has been particularly true of systemic claims of discrimination where the Supreme Court seems wedded to a vision that only sees discrimination in the most blatant circumstances and is unable to identify patterns of discrimination when it is necessary to draw inferences of discrimination. In this last section I will also critique the current academic obsession with what is known as implicit bias and call instead for better ways to illustrate the subtlety and complexity of contemporary discrimination.

\section{ThE 1970s AND THE DEVELOPMENT OF Supreme Court DoCTRINE.}

\section{A. The Origins of Employment Discrimination Law.}

Title VII - the primary federal antidiscrimination law that targets employment -- was passed in 1964, became effective for private employers the following year and seven years later to public employers, and the statute immediately generated substantial case law and controversy. The Department of Justice, which had primary enforcement authority at the time, quickly filed lawsuits against several large unions and later targeted police and fire departments for their discriminatory practices, particularly their use of written examinations that adversely affected minority 
applicants. ${ }^{11}$ The NAACP Legal Defense Fund “(LDF”), in conjunction with a small North Carolina law firm, brought suit against major North Carolina employers, and many of the efforts of LDF and the Justice Department resulted in the important early Supreme Court cases. ${ }^{12}$

These cases were all of their era - filed in the late 1960s and early 1970s, the lawsuits targeted entrenched patterns of discrimination typically against employers with a history of overt exclusion, and the cases raised some difficult issues that have now largely been forgotten, both in casebooks and our legal imagination. For example, a number of the cases raised the issue of whether an employer was responsible for remedying its past discriminatory practices. Many of the cases involved seniority systems and the workforce imbalance that originated when discrimination was lawful, and in these circumstances, the Supreme Court held that the employer had no obligation to remedy those past practices. ${ }^{13}$ A decade later the Court would revisit the issue in a pay discrimination case - a case originally filed immediately after the statute became applicable to public employers - where past discriminatory pay decisions had a continuing effect on current pay. ${ }^{14}$ In that case, the Supreme Court, unanimously, held that the employer had a duty to remedy its past discrimination so long as an employee's current salary was affected. ${ }^{15}$ It is not entirely clear why the Supreme Court shifted gears when it came to pay discrimination, but it is certainly easier to remedy pay inequities than to uproot past hiring or promotion decisions, and it may also be that the Court was concerned that the pay inequities had not been remedied in the dozen years since the Act had been passed. ${ }^{16}$

11 See, e.g., Teamsters v. United States, 431 U.S. 324 (1977) (suing union for discrimination among drivers); United States v. Sheet Metal Workers Int'l Ass'n, Local Union No. 36, 416 F.2d 123 (8 $8^{\text {th }}$ Cir. 1969). See also United States v. City of Chicago, 385 F. Supp. 543 (N.D. Ill. 1974) (police); Officers for Justice v. Civil Serv. Comm’n, 371 F. Supp. 1328 (N.D. Cal. 1973) (police that included Justice Department involvement).

12 A number of seminal Supreme Court cases arose from North Carolina, in part because of an active law firm that brought many of the cases in conjunction with the NAACP Legal Defense and Educational Fund. See Albemarle Paper Co. v. Moody, 422 U.S. 405 (1975) (North Carolina paper company sued for discriminatory tests); Griggs v. Duke Power Co., 401 U.S. 424 (1971) (North Carolina energy company sued for discriminatory tests); Swann v. Charlotte-Mecklenburg Bd. of Educ. 402 U.S. 1 (1971) (Charlotte North Carolina desegregation case involving mandatory busing).

${ }^{13}$ See Teamsters v. United States, 431 U.S. 324, 353 (1977) (no obligation to remedy effects of legitimate seniority system implemented prior to Act's effective date despite its discriminatory nature).

${ }^{14}$ Bazemore v. Friday, 478 U.S. 385 (1986).

${ }^{15}$ Id. at 392.

16 To make the issue more concrete: In Bazemore the state of North Carolina had paid 
The famous case of Duke Power Company v. Griggs also fits the model described above. Duke Power, a large North Carolina energy company, had limited the employment opportunities of African Americans to its worst jobs until the day Title VII became effective. Thereafter, the employer required its employees to pass two written examinations in order to move out of those jobs. ${ }^{17}$ Whether or not the examinations were instituted with an intent to discriminate, there was little question that the effect of the examinations would be to perpetuate the company's segregated workforce, to leave things the way they had been, and the Court concluded that such a pattern would be contrary to the purpose behind Title VII. ${ }^{18}$ Although in Griggs, the Court did not require the employer to remedy its past practices, it did require them to take steps to move away from a fully segregated workforce through what became known as the disparate impact theory. The important novelty of the case was that plaintiffs could establish a claim of discrimination without the burdensome need to prove an intent to discriminate. ${ }^{19}$ Discriminatory results and the lack of an adequate justification was sufficient to prevail on a claim, and likewise was defined as unlawful discrimination.

These cases highlight how the Supreme Court was creating law against a particular historical backdrop, a backdrop of pervasive and overt exclusionary practices. As a statute, Title VII is notoriously short-winded so it was necessary for the Court to give meaning to the particular provisions and it did so primarily by emphasizing the purpose behind the statute, which was to end the segregated practices but with a minimal amount of disruption among existing employees. ${ }^{20}$

its African-American extension agents less than its white agents until Title VII forbade such practices. Thereafter, the question was whether the state had an obligation to eliminate those past disparities rather than just moving forward with equal pay scales or salary increases. Id. at 394. With the seniority systems, the question was whether an employer was obligated to disrupt the seniority system that preexisted Title VII where only whites typically had access, and accrued seniority, for the most desirable jobs.

17401 U.S. at $427-28$.

18 Id. at 436. One reason for this was, as the Court noted, the discriminatory and deficient education that had been provided to African Americans within North Carolina. Id. at 430 ("Because they are Negroes, petitioners have long received inferior education in segregated schools ...”).

19401 U.S. at 429.

20 This is where the seniority cases came in. Although there was little question that white individuals, almost always white men, had benefited by past discriminatory practices, the Court determined it was too late to disrupt their employment and thus focused on prospective changes. Teamsters, 431 U.S. at 379. 
Other cases that arose at the time also involved explicit discriminatory practices and the perpetuation of past discrimination. The explicit cases typically involved gender restrictions and the very first case that arose under Title VII struck down an employer's refusal to hire women with children, a variant of a similar case that had arisen under an entirely different statute. $^{21}$ Another early case restricted the employment opportunities of women who sought to work in male prisons, ${ }^{22}$ and the Court also considered the permissibility of an employer's practice of hiring by word of mouth for its construction jobs.

This latter case, Furnco v. Waters, raised a number of thorny issues that had befuddled the lower courts. ${ }^{23}$ There were two related questions present in the case - could employers use word-of-mouth recruiting, was such a practice lawful, and in addition, the case also raised the question whether an employer should be required to use employment practices that would maximize opportunities for minority workers. ${ }^{24}$ As anachronistic as it may seem today, the Court of Appeals had held that the employer must adopt the practice that would best open up positions for minority workers, a conclusion the Supreme Court ultimately rejected, while also holding that word-of-mouth, or subjective decisionmaking, was not a per se violation of Title VII. $^{25}$ In Furnco, and as was true in Griggs and the gender cases, we see the Court making judgments about what kinds of practices were permissible, what kinds of practices the new statute was designed to eradicate. At the same time, the Supreme Court tempered the law's development by holding only that employers refrain from discriminating rather than being required to hire more minority workers.

During the same Term as the Furnco case was decided, the Supreme Court addressed two cases that raised issues regarding the role of statistics in proving claims of discrimination. Although it is now widely accepted that statistics are an essential tool for proving class action claims, these

\footnotetext{
${ }^{21}$ See Phillips v. Martin Marietta, 400 U.S. 542 (1971). The famous case of Monell v. Department of Social Services, 436 U.S. 658 (1978), which permitted suits under 42 U.S.C. $\S 1983$, involved a New York City policy of requiring pregnant women to take unpaid leave.

22 Dothard. v. Rawlilnson, 433 U.S. 321 (1977).

23 The Furnco case involved an employer's practice of hiring only bricklayers who the Plant Superintendent knew or were referred to him, which resulted in a nearly all-white group of bricklayers. See Furnco Constr. Co. v. Waters, 438 U.S. 567, 571 (1978).

24 Id. at 577.

25 Id. at 578 (noting that the employer is not required to adopt practices that will maximize opportunities for minority workers) and $580 \mathrm{n} .9$ (rejecting challenge to subjective practices as discriminatory) .
} 
early cases raised the question whether statistics could be relied on to prove an intent to discriminate. Here the Court was addressing in a class action context the very same issue it had previously addressed in an individual case - under what circumstances should courts draw inferences of discrimination ${ }^{26}$ The two cases involving the use of statistics were similar in nature and both were brought by the Department of Justice. In the Teamsters case, no African- Americans held the most prestigious job of long-distance driver, even though about five percent of the company's workforce was African American. ${ }^{27}$ The second case involved a suburb just outside St. Louis, where there were very few African-American teachers, even though just over fifteen percent of the teachers in the City of St. Louis were African American. ${ }^{28}$ Both cases presented strong grounds for identifying discrimination as a cause of the workplace imbalances because both defendants had a long and open history of excluding African Americans. $^{29}$ Both cases were also a product of their time, as they presented questions of the employer's duty to remedy past discrimination, one in the form of a seniority system and the other in the form of a deeply imbalanced workforce that experienced relatively little turnover.

Most important to the development of the law, the cases involved the use of statistics to establish an intent to discriminate, and both relied on relatively unsophisticated statistical claims. The question posed in both cases was whether discrimination could be defined as the cause of the workforce imbalance. Put more directly, why were there no African Americans among the long-haul truck drivers, even while there were a significant number who worked the shorter routes? Similarly, why were there so few African-American teachers in Hazelwood, particularly when many qualified African- American teachers were working nearby in the City of St. Louis? Statistics came into play by demonstrating that the workforce compositions were not likely a chance occurrence - when the numbers were so stark, statistical analysis could rule out chance as a likely cause and at this point in time, courts were willing to assume discrimination was, therefore, a likely cause. Neither case involved extensive analysis of

${ }^{26}$ In the context of individual claims, the case is McDonnell Douglas Corp. v. Green, 411 U.S. 792 (1973).

27 Id. at 337.

28 Id. at 303.

${ }^{29}$ For example, in Hazelwood the Court noted that Hazelwood hired its first AfricanAmerican teacher in 1969, and by 197322 of the 1231 (or 1.7\%) were African Americans. In contrast, of the 19,000 teachers employed in the St. Louis area, 15.4\% were African American. Id. In Teamsters, the government "bolstered its statistical evidence with the testimony of individuals who recounted 40 specific instances of discrimination." Teamsters, 431 U.S. at 439. 
statistics, and both borrowed loosely from an earlier case that addressed the same issue but in the context of a jury composition - namely at what point could we assume the absence of African Americans in a jury pool was the product of discrimination. ${ }^{30}$

These last three cases represented important statements by the Court regarding employers' obligation to remedy past discrimination, and also in the way the Court would define discrimination moving forward. Statistics could plainly establish an inference of discrimination but at the same time, an employer had no obligation to uproot existing employees or to adopt practices that would most clearly benefit African Americans. An employer, for example, might argue that it had so few African-American teachers because it had previously discriminated against them when it was allowed to do so and it simply had not done enough hiring to change that balance. An employer might also argue that too few African Americans were qualified for the positions or were not interested in them and it soon turned out that many courts were relatively quick to accept such explanations. Indeed, after establishing the broad parameters for proving discrimination, the Supreme Court began to pull back from its broad protective stance by noting, what has now become talismanic in employment law, "Courts are generally less competent than employers to restructure business practices and unless mandated to do so by Congress they should not attempt it."31

While the Court was developing Title VII law, it also began to confront the complicated issue of affirmative action. The well-known Bakke case ${ }^{32}$ was decided the same year as Furnco, and shortly thereafter the Court addressed two affirmative action cases that arose under Title VII. Both of those cases were essentially identical to the Teamsters case in that unions had been sued for their history of discrimination. The main difference was that the Title VII affirmative action cases involved remedial questions, and the law of affirmative action became divided between claims that were designed to remedy past discrimination and the diversity justification that was ultimately established in Bakke. ${ }^{33}$ Employers, the

30 In conducting a rudimentary statistical analysis, the Court borrowed from its very recent precedent in a jury discrimination case. See Castaneda v. Partida, 430 U.S. 482 (1977). In that case, the Court employed a standard deviation analysis to determine whether the observed disparities might be attributable to chance or whether something else, such as discrimination, likely explained those disparities. The Court performed the same analysis in Hazelwood. See Hazelwood, 433 U.S. at 311 n.58.

${ }^{31}$ Furnco, 438 U.S. at 578.

${ }^{32}$ Regents of University of California v. Bakke, 438 U.S. 265 (1978).

33 See United Steelworkers v. Weber, 443 U.S. 193 (1979) (upholding private affirmative action program that was designed to address past practice that had largely 
Supreme Court concluded, could administer affirmative action programs, even ones that contained quotas, so long as the programs were designed to remedy past or present discrimination. ${ }^{34}$ Without a remedial justification, entities, and this became relevant primarily for educational entities, could use race as a factor in its decisions so as to provide greater diversity to a class, and an employer might also be able to use gender, the Court later said, to address a manifest imbalance in its workforce. ${ }^{35}$

By the end of its first decade interpreting Title VII, half of the Court's decisions, and all of the large class action cases, involved employers with a demonstrated history of discrimination. Even though some of the cases, like Griggs, involved the creation of substantive law, a central question in all of the cases involved a mandate to prevent the perpetuation of past practices and the discrimination that flowed from those practices. This was a slightly different question from whether employers had an obligation to remedy those past practices but it was clear the Court was trying to steer the law into a different era. And by the end of the decade that different era seemed to have arrived. The affirmative action cases presented an important but underappreciated change in direction: within ten short years the Court had gone from focusing on employers with a clear history of discrimination to employers, and educational entities, that sought to take voluntary action to diversity the workplace or student body. From this perspective, the interests of employers were becoming more aligned with racial minorities and women, and the concern for judicial supervision switched from employers who were discriminating to employers who were seeking to benefit women and minorities at the expense of white employees.

Not only was the Court grappling with the divisive issue of

excluded African Americans from certain positions). Another case arose a few years later in which the Court upheld an affirmative action plan that a court had imposed upon a union to remedy past discrimination and the union's refusal to address its discrimination. See Local 28 of Sheet Metal Workers’ Int'l Ass’n v. EEOC, 478 U.S. 421 (1986).

34 In Weber, the Supreme Court upheld a voluntarily-implemented affirmative action program that was designed to address a racial imbalance in the workforce. One aspect of the case that is often overlooked is that the imbalance was the direct result of the overt exclusion of African-Americans from craft positions. See 443 U.S. at 198. In footnote one of its Opinion, the Court listed many findings of overt exclusion. See id. at n.1. The Sheet Metal Workers case involved a judicially imposed affirmative-action plan designed to remedy a lengthy, and judicially determined, history of discrimination against African Americans. See Sheet Metal Workers, 478 U.S. at 428-40 (describing the history).

35 See Johnson v. Transp. Agency of Santa Clara County, 480 U.S. 616 (1987) (upholding a voluntary affirmative plan designed to address a significant gender imbalance in the workforce). 
affirmative action but it also was addressing the even more controversial issue of school busing as a means of remedying our segregated past. Although the Court gave a rather broad imprimatur to busing as a remedial measure at the beginning of the decade, ${ }^{36}$ by the middle it had signaled a major change by limiting the power of school districts to breach district lines to integrate schools, giving force to what came to be called white flight. $^{37}$ Indeed, by the end of the decade, the very concept of discrimination had changed as had the Court's fidelity to broad remedial measures to address discrimination. ${ }^{38}$

The most important insight to be drawn from the cases is that they were borne of an era, and none of the cases, including Griggs, produced any detailed discussion of how discrimination was to be proved or identified. Most of the cases were not complicated and all involved stark exclusions: in Griggs, African Americans were confined to the laborer jobs, in Teamsters there were no African-American long distance drivers; in Hazelwood, there were strikingly few African-American teachers; in Furnco, there were no black bricklayers; in the gender cases, there were no pregnant teachers and no women working in male prisons or as construction dispatchers. As a result, because the cases were so clear, the Court provided broad pronouncements about what kinds of acts were or were not discriminatory, often in potentially contradictory form. For example, while the Supreme Court held that workforce underrepresentation, by itself, was not evidence of discrimination, strong statistical proof could establish an intent to discriminate. ${ }^{39}$ In making these pronouncements, the Court failed to recognize that the statistical proof involved little more than documenting underrepresentation in the workforce, and it would be another thirty years before the Court sought to reconcile those contradictory impulses. ${ }^{40}$

36 See Swann v. Charlotte-Mecklenburg Board of Education, 402 U.S. 1 (1971) (upholding busing plan to address segregation).

37 See Milliken v. Bradley, 418 U.S. 717 (1974) (striking down a busing plan that crossed school district boundaries).

${ }^{38}$ In addition to the cases discussed above, this was signaled in the important case of Personnel Administrator v. Feeney, 442 U.S. 256 (1979), in which the Court upheld the use of veteran's preferences against a constitutional gender discrimination challenge. Notably, in that case the Court held that an "awareness of [the] consequences" of an act is not the same as purposeful discrimination. Id. at 279. The Supreme Court also upheld a policy, against a disparate impact challenge, that prohibited the hiring of drug users, including those who were using methadone. See New York City Transit Authority v. Beazer, 440 U.S. 568 (1979).

${ }^{39}$ Hazelwood, 433 U.S. at 307-08 ("Where gross statistical disparities can be shown, they alone may in a proper case constitute prima facie proof of a pattern or practice of discrimination.”).

40 Many of the early cases, including Teamsters, Hazelwood, Griggs, Furnco, Sheet 


\section{B. The Political Backlash of the 1980s.}

By the end of the seventies, the Court had come full circle, from an acknowledgement that discrimination was pervasive and needed to be remedied to a modest questioning of the relevance of the antidiscrimination laws with a concern that employers were now going too far in their efforts to address past discrimination. That modest questioning would take a serious skeptical turn in the nineteen eighties when the Supreme Court adopted the distinctly conservative political views that were in vogue at the time. For a variety of reasons, this period has little to do with the contemporary doctrine so I will only spend a brief time discussing the Court's hostile turn, which really began in the early 1980s but picked up speed with the addition of Justice Scalia to the Supreme Court in the mid1980s. ${ }^{41}$

With the passage of time, it is easy to forget the powerful influence President Ronald Reagan had on the courts and more broadly, on the role the courts should play in modern life or in fomenting social change. The Reagan Revolution was premised in significant part on creating a more limited role for the courts, and it was also distinctly hostile to the civil rights legacy. Opposition to affirmative action was a central tenet of the administration's policies and it quickly set out to refashion the judiciary and civil rights enforcement. ${ }^{42}$ The Reagan Administration appointed decidedly conservative and often high profile individuals to the federal courts to an extent that seems unthinkable today. These included the well-known conservative scholars Richard Posner and Frank Easterbrook from the University of Chicago, as well as Robert Bork but also included Edith Jones and Patrick Higginbotham to the Fifth Circuit Court of Appeals, and very young judges such as Alex Kozinski and Diarmud O'Scannloin to the Ninth Circuit of Appeals. Likely the most important appointment was the

Metal Workers, Weber, were primarily focused on statistical imbalances in the workforce. The Court did not return to the issue until the recent Wal-Mart case, dicussed infra

41 Justice Scalia joined the Court for the Term that began in October 1986 and within six months, in his very first case involving employment issues, he issued a stinging dissent on a gender discrimination affirmative action case. See Johnson v. Transportation Agency, Santa Clara County, 480 U.S. 616, 657 (1987) (Scalia, J., dissenting).

${ }^{42}$ For discussions of the approach of the Reagan Administration see NORMAN C. AMAKER, Civil RIGHTS AND THE REAGAN ADMINISTRATION (1988); RAYMOND WOLTERS, Right TURN, WiLLIAM BRADFORD REYNOLDS, THE REAGAN ADMINISTRATION AND BLACK Civil Rights (1996). A more recent and excellent reflection on the era is DANIEL T. RODGERS, AGE OF FRACTURE (2011). 
placement of now Justice Antonin Scalia on the D.C. Circuit. ${ }^{43}$

The appointment of Justice Scalia to the Supreme Court marked the highwater moment for the conservative revolution and also began the intensive reconsideration of settled antidiscrimination doctrine. In the mid1980s, the Supreme Court began to issue what became a series of highly controversial and hostile civil rights decisions, many of which modified or overturned prior decisions. ${ }^{44}$ The attack by the Court was relentless and largely embodied the political views of the Republican party, which saw the civil rights era as having evolved into a racial entitlement program. Although the Court was unsuccessful in eliminating affirmative action, ${ }^{45}$ it did manage to cut at the margins, particularly with the various contract setaside programs that existed at the time. ${ }^{46}$ It also significantly revised the law governing educational desegregation in what might be described as the beginning of a wind down period. ${ }^{47}$

When it came to employment discrimination law, the Supreme Court set its sights on the disparate impact theory, and sought to restrict the force of that doctrine through the highly controversial decision of Wards Cove v. Atonio. ${ }^{48}$ The disparate impact doctrine had always been high on

43 Much has been written about President Reagan's effort to transform the judiciary in his conservative image. See, e.g., BERnARD SchwARTz, THE NEW Right AND THE Constitution 220-22 (1990); Sheldon Goldman, Reagan's Judicial Legacy: Completing the Puzzle and Summing Up, 72 JudiCATURE 318 (1988-89); Walter F. Murphy, Reagan's Judicial Strategy, in LOOKING BACK ON THE REAGAN PRESIDENCY (L. Berman ed., 1990).

44 Many of the cases involved issues relating to employment discrimination and were largely overturned by the passage of the Civil Rights Act of 1991 . The major cases were: Patterson v. McLean Credit Union, 491 U.S. 164 (1989) (limiting scope of section 1981); Martin v. Wilks, 490 U.S. 755 (1989) (permitting collateral attacks on consent decrees); Wards Cove Packing Co. v. Atonio, 490 U.S. 641 (1989) (altering and tightening the standards for proving disparate impact claim).

45 The Supreme Court took up several cases in the 1980s that seemed to have the potential to sharply limit the use of affirmative action but most of the cases fizzled. See Firefighters v. Cleveland, 478 U.S. 501 (1986) (upholding consent decree that allowed relief for individuals who were not actual victims of the challenged discriminatory practices); Firefighters v. Stotts, 467 U.S. 561 (1984) (reversing court injunction preventing the use of seniority-based layoffs as inconsistent with consent decree).

${ }^{46}$ See Adarand Constr. v. Pena, 515 U.S. 200 (1995) (applying strict scrutiny to federal set-aside program and rejecting prior case establishing lower standard of review); City of Richmond v. Croson, 488 U.S. 469 (1989) (applying strict scrutiny to strike down local setaside program).

${ }^{47}$ See Freeman v. Pitts, 503 U.S. 467 (1992) (permitting incremental release from consent orders even though jurisdiction had not obtained full compliance); Board of Education v. Dowell, 498 U.S. 237 (1991) (allowing jurisdiction to be released from court supervision when it obtained desegregation "to the extent practicable”).

48490 U.S. 642 (1989). 
the conservative list of targets because it was widely associated with affirmative action. Because the disparate impact doctrine did not require proof of intent and largely turned on establishing statistical disparities in a workforce, one way for employers to avoid disparate impact lawsuits, the argument went, was to hire by the numbers. ${ }^{49}$ This was a crude but influential interpretation of the doctrine and in the Wards Cove case, the Court sought to make it more difficult for plaintiffs to succeed on such claims on two different levels. The Supreme Court rejected the plaintiffs' statistical analysis and also shifted the burden of proof to plaintiffs on a critical element of the proof structure. ${ }^{50}$

At the time, all of this was incredibly important and could have altered the doctrine significantly. But the Court ultimately overplayed its hand and Congress stepped in almost immediately after the Wards Cove decision was issued to address the litany of cases the Court had issued that were hostile to employment discrimination plaintiffs. It took two years but Congress ultimately passed the Civil Rights Act of 1991 (“CRA 1991”), a statute that was designed to overturn or modify seven Supreme Court decisions. ${ }^{51}$ This was a powerful and influential rebuke of the Supreme Court, and as I have commented elsewhere, the statute seemed to restrain the Supreme Court for nearly two decades. ${ }^{52}$ Following the CRA 1991, the Supreme Court moved cautiously and plaintiffs fared much better in the cases that came before the Court, with an important exception. While in the late 1980s, the plaintiffs failed on virtually all of their cases, after the CRA 1991 plaintiffs prevailed in the majority of cases other than those that

49 This was a standard argument raised at the time and one that was used to challenge both the Civil Rights Act of 1990 (vetoed) and the Civil Rights Act of 1991 (passed). Indeed, President Bush's veto message for the 1990 Act included a reference to the quota issue. See Steven A. Holmes, President Vetoes Bill on Job Rights; Showdown is Set, N.Y. TimEs, Oct. 23, 1990, at A1 (quoting veto message as stating that the bill "employs a message of highly legalistic language to introduce the desctructive forces of quotas into our national employment system.”). See also CHARLES FrIED, Order WITHOUT LAw: ARGUing the REAGAN REVOLUTION - A FIRSTHAND ACCOUNT 119 (1991) (explaining role of quotas in opposition to legislation).

50 See Wards Cove Packing Co v. Atonio, 490 U.S. 642 (1989). The Court's reasoning on the statistical analysis, namely that the plaintiffs relied on an unrefined statistical analysis that failed to account for necessary job qualifications, remains the law today and was not a significant departure from prior law. See id. at 654. The shifting of the burden of proof was a major change in the law and ultimately overturned by the Civil Rights Act of 1991. See id. at 660.

51 See Pub. L. No. 102-166, 105 Stat. 1071 (codified as amended in scattered sections of 29 U.S.C. and 42 U.S.C.).

52 See Michael Selmi, The Supreme Court's Surprising and Strategic Response to the Civil Rights Act of 1991, 46 WAKE FOREST L. REV. 281 (2011) (discussing the Supreme Court's reaction to the passage of the Civil Rights Act of 1991). 
touched on substantial political issues. ${ }^{53}$

It is important, however, to explain the difference between the hostility of the Supreme Court in the 1980s and its more recent judicial reconsideration of the doctrine. In the 1980s, Supreme Court's decisions seemed decidedly political in nature, and did not appear to be in response to a substantial decrease in discrimination. Indeed, some of the hostile decisions were issued within half a dozen years of the expansive cases involving the proof of intent through statistics. The doctrinal changes in the late 1980s were politically motivated whereas, although the current Court remains conservative in orientation, the more recent cases are about seeking to adjust the doctrine to meet changing social conditions, an issue explored in detail in the next section.

\section{The COURT’s RECEnT Updating OF THE DOCTRINE.}

The seventies marked the Court's development of employment discrimination doctrine, and the latter half of the 1980s witnessed a substantial and what was a politically-inspired retrenchment of protections for the victims of discrimination. That retrenchment led to the statutory action in the form of the Civil Rights Act of 1991, which provided new remedies and also reversed a series of Supreme Court decisions. The following decade primarily was relatively quiet, with modest doctrinal innovations and a series of relatively minor procedural decisions. ${ }^{54}$ It was only recently that the Court began to revisit its earlier doctrine with a concerted eye towards aligning that doctrine with contemporary social conditions.

\section{A. Ledbetter v. Goodyear Tire: Rejecting the Continuing Violations Doctrine.}

The case involving Lilly Ledbetter's challenge against Goodyear was the first of the recent cases in which the Supreme Court began to realign its existing legal principles. Like some of the other recent cases, Ledbetter had all of the trappings of a case that easily could have arisen in

53 See id. at 295-98.

54 See, e.g., O’Connor v. Consol. Coin Caterers Corp., 517 U.S. 308 (1996) (age discrimination plaintiff need not prove that she was replaced by person who falls outside of protected class); Robinson v. Shell Oil, 519 U.S. 337 (1997) (former employees can pursue claims); Federal Express Corp. v. Holowecki, 552 U.S. 389 (2008) (broadly interpreting filing requirement consistent with EEOC regulations). Some of these cases, like Robinson above, were designed to overturn outlier decisions by a single appellate court. 
the 1970s. Lilly Ledbetter was the first, and for most of her employment history, the only female supervisor in the Alabama Goodyear plant where she worked. $^{55}$ During her employment, she encountered a series of problems and eventually discovered that she was the lowest paid supervisor, even though she had greater seniority than many of her male peers. Towards what would turn out to be the end of her Goodyear career, Ledbetter filed a charge with the EEOC raising various claims of discriminatory treatment, including a salary discrimination claim. ${ }^{56}$

When the case reached the Supreme Court, Ledbetter was seeking to recover for the salary discrimination she had experienced throughout her career even though she had not filed a claim until just before she resigned. Although under Title VII's short filing deadlines Ledbetter's salary claim would have been time-barred, there was precedent - in this instance from the 1980s case of Bazemore v. Friday - that seemed to support allowing her claim to go forward. That case involved the segregation and subsequent pay claims of the North Carolina Agricultural Extension Service, which prior to the effective date of Title VII had two separate divisions based on race and paid the African-American agents substantially less than their white counterparts. ${ }^{57}$ Much of that pay discrimination arose prior to the effective date of the Civil Rights Act, and part of the Bazemore case concerned whether an employer had an obligation to remedy pay discrimination that originated when such discrimination was permissible. In language that seemed to apply directly to Ledbetter's situation, the Supreme Court, unanimously held that the extension service must correct the current effects of the discrimination stating: "Each week's paycheck that delivers less to a black than to a similarly situated white is a wrong actionable under Title VII ...."58 In other words, the state was required to remedy the salary disparities even though they arose before the statute deemed them discriminatory.

But that language came twenty years before Ledbetter and involved a situation that originated in the 1970 s, a situation and time that was clearly different. In Bazemore, there was no delay in the filing of the complaint but rather the issue was whether the employer could continue to pay its African-

\footnotetext{
55 See Ledbetter v. Goodyear Tire \& Rubber Co., 550 U.S. 618, 643-44 (2007) (Ginsburg, J., dissenting).

56 Ms. Ledbetter was hired in 1979. In March 1998, she submitted a questionnaire to the EEOC and filed a formal charge of discrimination in July 1998. She took early retirement in November 1998, and subsequently filed her lawsuit. See 550 U.S. at 621-22.

57478 U.S. 385 (1986).

58 Id. at 395 (Brennan, J., joined by all Members of the Court, concurring in part).
} 
American agents less than the white agents because they had done so historically. From that perspective, the issue was largely the same as presented in the Griggs case: could the employer perpetuate past practices if that led to differential pay or a segregated workforce? In contrast, the issue in Ledbetter was quite different, namely why had she had not complained sooner and, relatedly, what it would mean if the Court allowed her claim to go forward to challenge what was alleged to be a career marred by discrimination. There was no easy answer to the first question regarding the lateness of her complaint, and surprisingly, none was offered. Instead, her attorneys sought to rely on the language from Bazemore without explaining why she had failed to complain during the course of her career. Oddly enough, the best explanation might have been true: she did not know about the pay discrimination until someone provided her with an anonymous note, which was the explanation she offered to the media after the case was decided but not to the courts. ${ }^{59}$ This is one way in which wage claims are distinct from other discrimination claims since employees often do not have wage information regarding their co-workers and will be unaware of any pay discrepencies. ${ }^{60}$

Another possible explanation reflects the changed landscape of antidiscrimination law, and while it may have resonated in an earlier era by the time the Ledbetter case came around it was effectively foreclosed. Employees frequently contend that they failed to file a timely complaint because they feared retaliation from their employer. ${ }^{61}$ Such a fear is surely not irrational, and retaliation remains a substantial concern for many employees. $^{62}$ At the same time, over the last decade the Supreme Court has created doctrine that is highly protective of retaliation claims, thus

59 Ms. Ledbetter provided her clearest explanation for why she failed to file a claim earlier in her Congressional testimony in support of the Lilly Ledbetter Fair Pay Act. See Testimony of Lilly Ledbetter before the U.S. Senate Committee on the Judiciary, Sept. 28, 2008. During her court case, she failed to offer an explanation for her delayed filing but instead sought to rely on the legal precedents to argue that her claim was timely. For a thorough discussion of the background see Charles A. Sullivan, Raising the Dead? The Lilly Ledbetter Fair Pay Act, 84 TUL. L. REV. 499, 507-10 (2010).

60 Often this lack of knowledge is due to employer policies that prohibit employees from discussing their pay. These policies likely run afoul of the protection of the National Labor Relations Act but remain common. For a discussion see Leonard Bierman \& Rafael Gely, Love, Sex and Politics? Sure. Salary? No Way: Workplace Social Norms and the Law, 25 BERKELEY J. EMP. \& LAB. L. 167 (2004).

61 The fear of retaliation, often well-founded, is discussed in Deborah L. Brake and Joanna L. Grossman, The Failure of Title VII as a Rights-Claiming System, 86 N.C. L. REV. 859, 903-905 (2008).

62 Id. at 905. 
presumably minimizing an employees' fear of retaliation. ${ }^{63}$ Indeed, this is one of the ways in which employment discrimination has evolved; no longer can an employee simply articulate a fear of retaliation to excuse a failure to file a claim since the Court has made it clear that the law will protect those who file complaints. And, in the context of a complaint-based system, it surely makes sense to require employees to file complaints so as to bring issues to the employer's attention.

As a result, the real issue in the case was whether the Court would apply its reasoning from Bazemore to allow Ms. Ledbetter's claim to go forward or whether it would find a way to distinguish or repudiate that case. If her claim had arisen in the 1970s or the 1980s, the Court likely would have allowed the claim to proceed but the passage of time highlighted the differences in the cases. As noted, Bazemore involved the continuation of pay discrimination from the time the extension service had lawfully segregated its employees - it was blatant and relatively easy to measure, and a circumstance that would have a finite ending. ${ }^{64}$ Once the Supreme Court announced in Bazemore that an employer was obligated to remedy pay discrimination that occurred prior to the effective date of the Civil Rights Act, employers would presumably correct those pay disparities. In other words, this was a quintessential first generation issue. In contrast, if Lilly Ledbetter's claim were allowed to move forward, salary claims would always remain alive so long as a past discriminatory, and typically discrete, act had current effects. From an employer's perspective, these two issues were dramatically different.

Not surprisingly, the Court dismissed Ms. Ledbetter's claim but did so in a disingenuous way. Rather than stating that the Bazemore language was designed to address a different issue from a different era, it chose to distinguish the case by emphasizing that the policy at issue in Bazemore was facially discriminatory. ${ }^{65}$ This was simply untrue; indeed, the state of North Carolina had argued for a decade that its current salary structure was

63 This issue is discussed in more detail below but by the time the Ledbetter case was decided, the Supreme Court had issued a series of cases that provided strong protections relating to retaliation claims. See, e.g., Burlington Northern \& Santa Fe Ry. Co. v. White, 548 U.S. 53 (2006) (adopting liberal standard for determining when an individual had been retaliated against).

64 Bazemore v. Friday, 478 U.S. 385, 391 (1986) (per curiam) (discussing the perpetuation of pay disparities).

65 The Court distinguished the situations by emphasized that Bazemore involved a "facially discriminatory pay structure that put[] some employees on a lower scale because of race ..." Ledbetter, 550 U.S. at 634. 
free of any past discrimination. ${ }^{66}$ As will be true in the other cases discussed in this article, the Supreme Court sought to distinguish rather than overturn its precedent, and in doing so, emasculated that precedent, which had the effect of serving the same function as if it had been overruled. There simply are no more facially discriminatory pay structures, and thus the Bazemore decision is no longer applicable to contemporary pay cases.

There was a related but implicit issue the Supreme Court was addressing in Ledbetter and that is the confounding issue of the "present effects of past discrimination," or what is sometimes known as the continuing violations doctrine. This was an issue that had some vitality in the early years of Title VII but never gained currency because there was no ready definition of what constituted a continuing violation. ${ }^{67}$ The Ledbetter situation was one such example - the effects of salary determinations made early in her career had a continuing effect on her later salary but that seemed unsatisfactory because it would apply to all such situations, even if the entity itself had implemented clear nondiscriminatory policies in the intervening years. So in one fell swoop, the Bazemore decision and the continuing violations doctrine were gone.

\section{B. AT\&T v. Hulteen and Lost Pension Rights.}

Of the four cases discussed in this section, AT\&T v. Hulteen was likely the least controversial and is similarly likely to be the least influential. $^{68}$ Like Ledbetter, the case involved an allegation of discrimination that had occurred some thirty years earlier but the underlying question was whether the employer had a duty to remedy that discrimination, an issue that mirrored those the Court addressed in the formative 1970s period. There was, however, a significant difference with the Ledbetter case that may have made Hulteen potentially more attractive

66 Prior to the Ledbetter decision, Bazemore had been interpreted by lower courts for twenty years and none had emphasized the facially discriminatory nature of the original pay scale. See Shear v. Rice, 409 F.3d 448, 452 (D.C. Cir. 2005) (applying Bazemore to allow claim to go forward because plaintiff had received "less pay with each paycheck"); Cardenas v. Massey, 269 F.3d 251, 257 ( $3^{\text {rd }}$ Cir. 2001) (following Bazemore to conclude “each pay check constituted a distinct paycheck").

${ }^{67}$ The continuing violations doctrine typically meant one of three situations. One was a practice or policy that was, in fact, continuing and therefore was subject to suit so long as the policy was in place. Other times the concept was a synonym for a pattern or practice claim, while occasionally it fell into some murky territory so that one court could say "the relevant strain of continuing violations doctrine is that a systematic policy of discrimination is actionable even if some or all of the events evidencing its inception occurred prior to the limitations period.” Williams v. Owens-illinois, 665 F.2d 918, 925 (9 $9^{\text {th }}$ Cir. 1982).

68556 U.S. 701 (2009). 
to the Court - the issue here was not why Hulteen had failed to complain earlier but whether the employer had a duty to address the effects of a discriminatory practice that directly affected current pension payouts.

One reason the Hulteen case felt old is that it was. The plaintiffs had all taken pregnancy leave prior to 1979 , under a policy that treated pregnancy leave discriminatorily but lawfully until 1978 when the Pregnancy Discrimination Act ("PDA") was enacted. 69 Once the PDA was passed, AT\&T changed its policy but it did not correct its prior practice that had failed to take into account pregnancy leave when calculating seniority and pension benefits. The plaintiffs argued that AT\&T had a duty to rectify its past practice but citing a series of cases that dated from the 1970s and 80s, the Court upheld the policy holding, in effect, that the company had no duty to remedy a practice that was lawful when enacted. ${ }^{70}$

Together Hulteen and Ledbetter put an end to the eighties' notion of a continuing violations theory, and the related concept of the present effects of past discrimination. These concepts, including the Bazemore case, had survived in the lower courts but had not found their way into the Supreme Court for decades. The era of correcting discrimination that arose years ago has now officially ended. The next two cases took up important concepts regarding class action cases and patterns of discrimination, and as was true with the present effects of past discrimination, the Court was reluctant to make the old clothes fit the new emperor.

\section{Ricci v. DeStefano: Rejecting the Disparate Impact Theory.}

The case of Ricci $v$ DeStefano involved discriminatory tests that were administered by the City of New Haven for promotions within its fire department. Although the procedural posture was different, the underlying facts of the Ricci case offered a carbon copy of the many testing claims that had arisen involving fire or police examinations reaching back several decades. Cases involving police and fire departments were among the very first cases brought by the United States Civil Rights Division within the Department of Justice, in large part in response to the Kerner Commission Report that had concluded that one of the reasons for the urban riots of the late-1960s was because the composition of police departments failed to

${ }^{69} \mathrm{Id}$. at 705.

${ }^{70}$ Virtually all of the cases the Court relied on were decades old. See California Brewers Assn. v. Bryant, 444 U.S. 598 (1980); Trans World Airlines, Inc. v. Hardison, 432 U.S. 63 (1977); Teamsters v. United States, 432 U.S. 324 (1977); Nashville Gas Co. v. Satty, 4343 U.S. 136 (1977); Bazemore v. Friday, 478 U.S. 385 (1986). 
reflect their communities. ${ }^{71}$ As soon as Title VII became applicable to public employers, lawsuits were filed against most major cities and the vast majority of the claims involved challenges to written examinations. ${ }^{72}$

Those examinations had two common features: they were multiple choice tests that often had little connection to police or fire work and they uniformly had adverse impact against African Americans, and in some

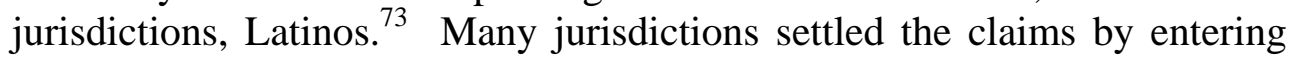
into consent decrees that provided for integrating the department while creating new examinations. ${ }^{74}$ Over time, the cases began to trail off and some moved to the promotional levels, but the underlying issue of the adverse impact of the examinations has never waned.

By all appearances, the Ricci case involved another first generation dispute. The New Haven fire department had a lengthy history of both discrimination and litigation, and this particular dispute involved promotional examinations for Lieutenant and Captain positions. The City

71 See National Advisory Commission on Civil Disorder Report, 9-11 (New York Times Ed. 1978) ("We have cited deep hostility between police and . . . communities as a primary cause of the disorders surveyed by the Commission . . . In practically every city that has experienced racial disruption since the summer of 1964 - abrasive relationships between police and [blacks] have been a major source of grievance, tension, and ultimately disorder."). The Report, originally published in 1968, concluded by recommending increased diversity so that departments better reflected the communities they served. Id. at 299.

72 See, e.g., United States v. City of Miami, 664 F.2d 435 (5 ${ }^{\text {th }}$ Cir. 1981) (police); United States v. Virginia, 620 F.2d 1018 (4 ${ }^{\text {th }}$ Cir. 1980) (Virginia State Police); United States v. Chicago, 549 F.2d 415 ( $7^{\text {th }}$ Cir. 1977) (police); United States v. San Francisco, 656 F. Supp. 276 (N.D. Ca. 1987) (fire); United States v. New Jersey, 614 F. Supp. 387 (D. N.J. 1985) (fire); United States v. Yonkers, 609 F. Supp. 1281 (S.D.N.Y. 1984) (police); United States v. City of Buffalo, 457 F. Supp. 612 (W.D.N.Y. 1978) (police and fire).

73 Many of the early tests were "off-the-shelf" tests that resembled IQ examinations and rarely had any obvious connection to police work. The test at issue in the famous case of Washington v. Davis, 426 U.S. 229 (1976) asked logical reasoning questions that one might find in an SAT examination. A copy of that test was attached as an Appendix to the appellate court decision (Davis v. Washington, 512 F.2d 956, 967 (D.C. Cir. 1975)) and is discussed in Michael Selmi, Was the Disparate Impact Theory a Mistake? 53 UCLA L .REV. 701 (2006).

${ }^{74}$ See, e.g., Detroit Police Officers' Ass'n v. Young, 608 F.2d 671 (6 ${ }^{\text {th }}$ Cir. 1979) (upholding police department's voluntary affirmative action plan); Officers for Justice v. Civil Service Comm'n, 688 F.2d 615 ( $9^{\text {th }}$ Cir. 1982) (approving consent decree for San Francisco police department); United States v. City of Philadelphia, 499 F. Supp. 1196 (E.D. Pa. 1980) (entering consent decree in challenge to employment of women in Philadelphia Police Department). For a discussion of the litigation regarding police and fire departments see Paul Burstein \& Susan Pitchford, Social-Scientific and Legal Challenges to Educ. And Test Requirements in Employment, 37 Soc. ProBS. 243 (1990). 
of New Haven is a diverse mid-sized city with approximately 130,000 residents, with whites comprising just over forty percent of the population, African Americans just over a third and Latinos making up a quarter. ${ }^{75}$ In contrast, the officer ranks within the fire department were nearly 80\% white, even though the firefighter ranks more closely resembled the city's

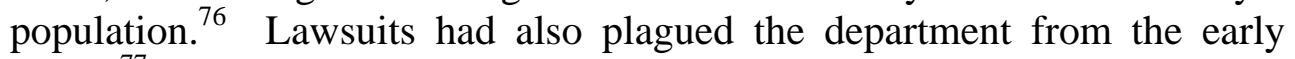
1980s. ${ }^{77}$

Although the Ricci controversy began in 2003, the similarities to the seventies-style litigation were hard to miss. For example, the disparity in the officer ranks was similar to what was typically found in the early cases, and the City created written examinations that were likewise similar to the kinds of examinations that were routinely administered in the seventies. In this respect New Haven was a contemporary outlier, as many jurisdictions had moved away from multiple-choice examinations to what are known as assessment centers, where leadership skills that are difficult to measure through written examinations are assessed through simulations. ${ }^{78}$ To be fair, the City was not entirely to blame for its continued reliance on written examinations - a negotiated agreement with the union, as well as a provision in the City charter, established the procedures and the scoring weights that were to be used for the firefighter promotional examinations. ${ }^{79}$ Yet, by all appearances, the City looked to be operating on principles that had been established in the seventies and eighties - principles that had been repeatedly successfully challenged in litigation.

75 These figures are from the 2010 census, and are available at http:/quickfacts.census.gov/qfd/states/09/0952000.html. Between 2000 and 2010, the population grew about 5\% with a significant influx (16.5\%) of foreign-born individuals.

76 As of 2003, African Americans constituted 30\% of the city's firefighters but only $9 \%$ of officer ranks at Captain or higher, while Hispanics represented $16 \%$ of the firefighter ranks but again only 9\% of the officers. See 557 U.S. at 611 (Ginsburg, dissenting).

77 The Fire Department's history of discrimination and related litigation is discussed in Cheryl I. harris \& Kimberly West-Faulcon, Reading Ricci: Whitening Discrimination, Racing Test Fairness, 58 UCLA L. REV. 73, 88-91 (2010).

78 Assessments center are commonly used for promotional examinations and have been demonstrated to be better predictors of performance than written tests. See, e.g., George C. Thornton III \& Michael J. Potemra, Utility of Assessment Center for Promotion to Police Sergeants, 39 Public Personnel MGt. 59 (2010) (documenting utility of assessment center process). Assessment centers have been around for many years. See, e.g., Joan E. Pynes \& H. John Bernardin, Predictive Validity of an Entry-Level Police Officer Assessment Center, 74 J. OF APPLIED PSYCH. 831 (1989).

79557 U.S. at 564 (noting that the contract with the union required that a written exam count for $60 \%$ of the score with an oral exam counting for $40 \%$ of the toral score) and id. (City charter requires use of written examinations). 
The other obvious connection to those older practices came with the examination results. Both the Captain's and the Lieutenant's examinations had substantial adverse impact, particularly when the focus was on where individuals placed on the examination rather than on the pass/fail rates. As is true with many public employers, the City was required to select its officers based on their specific scores with the additional caveat that the City could make its selection among the top three scorers. Given these restrictions, it appeared that no African Americans and perhaps one or two Latinos would be selected for the Captain positions and all of the Lieutenants would be white. ${ }^{80}$ This would have created a nearly all-white officers group in a diverse city with a diverse group of firefighters.

One aspect of the testing litigation that saw some change over the years is that the City of New Haven was troubled by the test results that excluded minority firefighters from the officer corps. ${ }^{81}$ This was also true in some of the early litigation, particularly where the City had undergone political changes so that the Mayor's office was occupied by an AfricanAmerican in a majority black city. ${ }^{82}$ Many of those cases were also settled and led to some of the more controversial Supreme Court rulings in the eighties that allowed white firefighters to challenge settlements even after they had been approved by a court. ${ }^{83}$ So even New Haven's concern for the adverse impact of the examination was not entirely new and the case undoubtedly looked like many of the cases that had previously come before the Court stretching all of the way back to the 1970s.

The twist, to the extent there was one, was that the City voluntarily determined that it would discard the test results and wait to make

80 The Supreme Court reported the numbers as follows: "Seventy-seven candidates completed the lieutenant examination--43 whites, 19 blacks, and 15 Hispanics. Of those, 34 candidates passed--25 whites, 6 blacks, and 3 Hispanics. Eight lieutenant positions were vacant at the time of the examination. As the rule of three operated, this meant that the top 10 candidates were eligible for an immediate promotion to lieutenant. All 10 were white. Subsequent vacancies would have allowed at least 3 black candidates to be considered for promotion to lieutenant. Forty-one candidates completed the captain examination--25 whites, 8 blacks, and 8 Hispanics. Of those, 22 candidates passed--16 whites, 3 blacks, and 3 Hispanics. Seven captain positions were vacant at the time of the examination. Under the rule of three, 9 candidates were eligible for an immediate promotion to captain--7 whites and 2 Hispanics.” Ricci, 557 U.S. at 566.

${ }^{81}$ The City's decision not to certify the test results after several days of hearings sparked the litigation. See id. at 574-75.

${ }^{82}$ For a comprehensive discussion regarding many cities see AFRICAN-AMERICAN Mayors: RaCe, Politics, AND the AMERICAN City (David R. Colburn \& Jeffrey S. Adler eds., 2001).

83 See Martin v. Wilks, 490 U.S. 755 (1989). 
promotions until a better examination could be developed. The City's decision followed a series of Commission hearings regarding the test results and at least nominally the validity of the test, though the City never commissioned or performed a formal validation study to determine the merits of the examination. ${ }^{84}$ Rather, the hearings suggested that the City might be vulnerable to a lawsuit if it promoted from the examinations given their substantial adverse impact. ${ }^{85}$ The dynamics of the New Haven fire department made this a situation the City could not win, as their decision to abandon the test results led to a lawsuit by the white firefighters.

In this respect, the litigation may have resembled some of the many reverse discrimination claims that were filed in the nineteen eighties but enough had changed since then so that the litigation also proceeded in a different direction. Outside of the intervention case - Martin v. Wilks - the reverse discrimination fury of the eighties never yielded the results antiaffirmative action zealots had expected, and much of that litigation subsided after the lower courts made it more difficult for such claims to proceed to trial. $^{86}$ But the change that captivated the Supreme Court was simply a matter of time - it was one thing for the Court to give the benefit of the doubt to challenges to adverse results in the seventies and eighties, a time when the segregated and inferior quality of most schools attended by minority students was still acutely present, and it was quite another to continue that stance some thirty years later.

To be more specific, when someone asked in the 1970s why the examinations had adverse impact, the answer was all but obvious and never really in dispute: African Americans had been provided with inferior education and training. This was, after all, the rationale that lay behind the creation of the disparate impact theory. ${ }^{87}$ But the same question did not yield the same answer thirty years later, and one of the odd aspects of

${ }^{84}$ The City's contract with the test developer contemplated the preparation of a "technical report." Id. at 566. Although it is not clear what the contents of the report would have been, or whether it would have served as a validation study, the City opted not to request the report.

${ }^{85}$ Id. at 572.

86 See Martin v. Wilks, 490 U.S. 755 (1989). The Wilks case was part of a litany of cases challenging the use of racial preferences in consent decrees with mixed results. For example, although the Court vacated an injunction prohibiting the use of seniority-based layoffs that were inconsistent with the terms of a consent decree (Firefighters v. Stotts, 467 U.S. 561 (1984)), it rejected a challenge to the use of broad remedial measures that went beyond what a court could have ordered as judicial relief. See Firefighters v. Cleveland, 478 U.S. 501 (1986). The Wilks case was subsequently superseded by a provision of the Civil Rights Act of 1991. See 42 U.S.C. § 2000e-2(a)(1).

87 See note 17 supra. 
disparate impact litigation is that the reason the examination has adverse impact is rarely at issue; the mere fact of adverse impact requires the employer to justify its practice. That may have made sense in an earlier era but by the time the Ricci case reached the Supreme Court, the presumption that the test results were the product of unequal educational opportunities was far more attenuated. And because of the way the cases unfold, no other explanation was offered, leaving the Court to its own assumptions regarding the source of the test disparities.

This is an important point that bears emphasis, particularly since it is central to the underlying claim I am advancing. I do not mean to suggest that racial inequities in education have been eliminated; far from it as our educational system remains stubbornly plagued by such inequities. ${ }^{88}$ Rather, what I mean to suggest is that the source of those inequities has changed - no longer can they be readily traced to the "separate but equal" regime that directly accounted for the disparities that led to the early disparate impact cases. Thirty years is a long time to be replaying the same dispute, and it would be a mistake to claim that the problems at issue in Ricci were the same that were at issue in Griggs.

This perspective focusing on changed social conditions helps explain the Court's Ricci decision, though as was true in Ledbetter the Court's discussion was anything but direct. It was clear, however, that whatever patience the Court had for the disparate impact theory has long since evaporated. Without at least some explanation for why the minority candidates fared worse than their white counterparts, it appeared that the disparate impact theory was no longer serving any purpose, particularly since among those who are not sympathetic to the disparate impact theory there are neutral explanations for the results. For example, the majority opinion alludes to the hard work of the white firefighters as an explanation

${ }^{88}$ Contemporary analyses of data continue to demonstrate substantial inequities across our educational system. This was the conclusion of a recent report commissioned by the Secretary of Education. See Equity and Excellence Commission, For Each and Every Child: A Strategy for Education Equity and Excellence 13 (2013) ("If on average, African American and Hispanic students performed academically at the level currently achieved by white students, overall student performance for the United States would rise from below the developed-country average to a respectable position ahead of, for example, Australia and Germany."). The Report goes on to identify many causes of the persistent inequality. See also Whither OpPORTUNITY? RISING INEQUALITY, SCHOOLS AND CHILDREN's LIFE Choices (G.Duncan \& R. Murnane eds. 2011); PATrick SHARKey, STUCK In Place: URbAN NEIGHBORHOODS AND THE END OF PROGRESS TOWARD RACIAL EQUALITY (2013); William SCHMidT AND CuRTIS MCKNIGHT, INEQuAlity FOR AlL: ThE Challenge OF UNEQUAL OPPORTUNITY IN AMERICAN SCHOOLS (2012). 
for the test results. ${ }^{89}$ Indeed, if the examination results are the product of merit, there is little reason why the disparate impact theory would displace those results so long after the original Griggs decision.

I do not mean to suggest that the results were the product of merit, rather I want to emphasize the assumptions or themes that underlie the Supreme Court's decision, and there is little question that in its decision to uphold the examinations, the Court saw the examination results as consistent with a meritocratic process. There was certainly good reason to question this assumption given that no evidence was ever introduced that would have established the validity of the tests, just as there was no meaningful evidence introduced regarding the reason for the adverse results.

These two facts - the absence of evidence on either the validity or the underlying results - demonstrate how the disparate impact theory no longer fits our social conditions, and in this respect, validates the Supreme Court's decision to uphold the challenge brought by the white firefighters. As noted previously, in the early years of the disparate impact theory, no evidence was necessary to explain the source of the adverse results, but it is difficult to indulge that same presumption today given the progress we have made over the last four decades. It certainly may be true that the minority firefighters attended inferior schools that left them ill prepared for written examinations, and it might also be that the more diffuse discrimination that African Americans and Latinos experience today limited their test taking abilities. Yet, the grounds for assuming these factors explain the test disparities are no longer as strong as they once were, and there is also the possibility that the white firefighters did study more for the test, and they might have done so not for any reason that would be tied to their whiteness but rather because a promotion might have meant something more to someone who came from a long line of firefighters, as is more commonly true for the white firefighters. $^{90}$ It was also possible that the white firefighters had simply been on the job longer.

\footnotetext{
89 Toward the end of the opinion, Justice Kennedy noted the "justified expectations" of the candidates and added, "Many of the candidates had studied for months, at considerable personal and financial expense, and thus the injury caused by the City's reliance on raw racial statistics at the end of the end of the process was all the more severe.” Id. at 593.

${ }^{90}$ See Stephen Reinhardt, Where Have You Gone, Jackie Robinson? 43 UCLA L. REV. 43, 45 (1995) (discussing the prevalence of family connections among white firefighters); Ann C. McGinley, Ricci v. DeStefano: A Masculinities Theory Analysis, 33 HARV. J. OF LAW AND GENDER 581, 587-92 (2010) (discussing urban firehouses with particular focus on New Haven).
} 
Whatever the reason, it is no longer feasible, or desirable to ignore these or other factors that might explain the examination results. Similarly, there is no longer any basis for assuming the test is discriminatory in its substance, an assumption that seems to continue to pervade popular mythology. There was nothing about this particular test to suggest that it was biased in a way that would favor white test takers. There were concerns that some of the questions were inappropriate for New Haven questions that asked about "downtown" that made little sense within New Haven and may have been borrowed from a New York City examination but there was no reason to believe that those questions would be racially skewed in a way that would favor whites. ${ }^{91}$ Questions were also raised about the costs of the material ${ }^{92}$ but again it is not clear why white firefighters would be more readily able to afford the cost of the study materials.

Perhaps the most mystifying part of the litigation was not the explanation for the disparate results but the fact that no one seemed interested in whether the examination provided any useful information. In fact, this was one of the original justifications for the disparate impact theory - the employer was required to justify the use of its test when the results clearly disfavored a historically disadvantaged group. ${ }^{93}$ Yet, despite its lengthy administrative and judicial history, there was no testimony in Ricci regarding how effective the examination was at choosing, or predicting, who would be successful officers. Ordinarily, this would be the issue at the center of a validation study, but the City eschewed any validation effort, and consistent with the rest of the litigation, did so without offering any explanation for its decision.

Something seems to have gone seriously awry when, more than forty years after the Civil Rights Act was passed, years of litigation can go by without anyone explaining either the reason for the disparate results or the validity of the examination - the two questions that should be the most critical part of any disparate impact inquiry. This is another sign that the old theory does not fit the new social conditions, and the Supreme Court effectively sent a message that these old-style claims would no longer have

91 See id. at 613 (Ginsburg, J., dissenting) (“A number of exam questions ... were not germane to New Haven’s practices or procedures.”).

${ }^{92}$ This issue was raised by Justice Ginsburg in her dissent. Id. In addition to the costs, she also noted that some individuals had to wait for a month and a half to receive the materials while others had obtained the materials earlier. Id.

93 See Griggs, 401 U.S. at 431. This is also one of the widely misunderstood parts of the disparate impact test - the presence of adverse impact does not invalidate the test, it only requires the employer to justify its use. 
an easy path. At least that is one way to read the case, and it is too early to see how lower courts might interpret the case. ${ }^{94}$ Another possibility is that the lower courts will simply treat this case as involving an employer's voluntary effort to address the adverse effects of its examinations and find little in the decision for the more common circumstance when plaintiffs sued to challenge the validity of the examination.

\section{Wal-Mart v. Dukes and Statistical Proof of Discrimination.}

In some ways the massive sex discrimination class action suit against the retailer Wal-Mart might appear to be a classic third generation claim. Here the plaintiff class was suing the world's largest retailer - one with a fierce reputation for litigating rather than settling - for companywide discrimination against its female employees in pay and promotions. Yet, the underlying claim in the case largely mapped onto a strategy that had been developed in the 1970s to challenge the hiring and assignment of women in grocery stores, and the statistical analysis that was offered turned out to be fairly rudimentary akin to a first generation claim, in this instance based on the earlier cases of Teamsters and Hazelwood.

Before proceeding further, it is important to note that the Wal-Mart litigation, in its original form, never proceeded beyond the class certification stage so it is quite possible that the attorneys representing the plaintiffs would have advanced a different and more sophisticated analysis at trial. $^{95}$ Nor should the following discussion be seen as a criticism of the plaintiffs' methodology, though I will say that they should have been aware that the Supreme Court was likely to view their evidence skeptically since it was so basic as to make it difficult to draw any broad conclusions in a world

94 To date only a handful of cases have sought to apply Ricci and most have distinguished the case. See Marashiello v. City of Buffalo, 709 F.3d 87 (2d Cir. 2013) (distinguishing Ricci in rejecting white firefighter's challenge to replacing old test results with a new promotional test); United States v. City of New York, 731 F. Supp. 2d 291, 298 (E.D.N.Y. 2010) (noting that "Ricci's specific holding does not control here, since a federal court attempting to remedy identified discrimination enjoys far more authority than an employer attempting to remedy potential discrimination."), vacated and remanded on other grounds, 717 F.3d 72 ( $2^{\text {nd }}$ Cir. 2013). In one case that was factually similar to Ricci, a District Court applied the case to hold the city liable for discarding test results. See Oakley v. City of Memphis, 2010 U.S. Dist. Lexis 143451 (W.D. Tenn. 2010).

95 The case was originally filed in 2001 and was litigated for more than ten years through the Supreme Court decision but never moved beyond the class certification stage. The Court of Appeals had twice affirmed the lower court's decision to certify the class, though there was a lengthy period between the two decisions. See Wal-Mart v. Dukes, 603 F.3d 571 ( $9^{\text {th }}$ Cir. 2010) (en banc), affirming lower court decision reported at 222 F.R.D. 137 (N.D. Cal. 2004). 
where gender discrimination is no longer perceived as the automatic explanation for segregated job patterns.

To provide some context to the case, it will be helpful to describe briefly the cases that were filed against grocery stores. Beginning in the 1970s, and continuing for the next thirty years, many of the largest grocery store chains were sued, particularly those on the West Coast where the plaintiffs' attorneys were based and the cases all followed a similar pattern that focused on the assignment policies of the stores. ${ }^{96}$ Within grocery stores, men were traditionally assigned to the most important departments meat and produce - while women tended to be clustered on the cash registers and in newer or less desirable departments such as bakeries and delicatesans. $^{97}$ These assignments ultimately led to lower pay and fewer promotional opportunities for women. One of the more interesting aspects of the litigation is that grocery stores traditionally post photographs of its management staff at the front of the stores and the attorneys would send paralegals into the stores to do a "visual" inspection of the management staff. $^{98}$ In addition to the photographic evidence, plaintiffs had rudimentary statistical data that charted how many women worked for the stores and their job assignments.

As was true with so many of the cases that arose in the 1970s and 1980s, the grocery store cases were not particularly complicated. Most of the grocery jobs required little education or experience so there was no real dispute about different qualifications for men and women, and this was also

96 I have discussed these cases previously. See Michael Selmi, Sex Discrimination in the Nineties, Seventies Style: Case Studies in the Preservation of Male Workplace Norms, 9 EMP. RTS. \& EMPLOY. POL'Y J. 1 (2005). Many of the cases were initiated in the 1980s. See, e.g., Hal Taylor \& Cathy Cohn, Four Chains Sued for Sex Bias, SuPERMARKET NEWS, Aug. 25, 1986, at 18.

${ }^{9}$ See Nicole Harris, Revolt at the Deli Counter, Bus. WK., April 1, 1996, at 32. A New York Times article summarized the allegations in one of the cases as: "The women said they were channeled into dead-end jobs, either working the cash registers or relatively new departments like bakeries and delicatessens, rather than the main grocery and produce sections . . . where jobs are generally better paid and can lead to promotions.” Jane Gross, Big Grocery Chain Reaches Landmark Sex-Bias Accord, N.Y. TIMES, Dec. 17, 1993, at A1. The case, one of the few with a published opinion, is Stender v. Lucky Stores, 803 F. Supp. 259 (N.D. Cal. 1992).

98 See, e.g., Christine Blank, Ingles Hit By Class-Action Sex-Bias Suit, SuPERMARKET NEWs, Mar. 9, 1998, at 4 (“A visual survey of management pictures in 39 Ingles' stores showed that $100 \%$ of the manager, assistant manager and produce, meet and grocery manager positions were held by men, the plaintiffs' lawyers said.”); Ann Hull, A Woman's Place, St. Petersburg Times, Feb. 2, 1997, at 1A (quoting a union representative as stating, "My God, you'd go in the stores and you didn't need a clipboard to write down what you saw. It was all white guys on those pictures.”). 
an industry where managers traditionally rose up through the ranks. The defenses offered by the grocery store chains typically involved claims of women's lack of interest in management jobs, or their refusal to relocate to find an appropriate position. ${ }^{99}$ This lack of interest defense, even at this early stage of the law, was also tried and true and thus provided these cases with an overlay from one of the best known of all sex discrimination cases the EEOC's case against Sears in which the company successfully defended a class claim that women were discriminatorily deprived of commission jobs by asserting that women lacked interest in the higher pressure sales positions. $^{100}$

The grocery store cases represented classic first-generation discrimination claims involving overt exclusions and often direct evidence in support of the discriminatory treatment of women. The cases also lent themselves to rudimentary statistical analysis, and often involved what the law describes as the "inexorable zero" where no women held the contested jobs. ${ }^{101}$ The statistics did little more than measure the disparity of women in those positions and offered an estimate of the likelihood that the job assignments occurred by chance; what, for example, was the chance that all of the women would end up in the bakery rather than behind the meat counter. The vast majority of the cases settled with minimal litigation beyond the class certification stage, which also established a pattern for similar cases while leaving a surprising dearth of case law in the area of statistical proof of discrimination. Following on the heels of the grocery store cases, a substantial claim was filed, and ultimately settled, against the retailer Home Depot that was based on similar allegations, namely that women were consigned to cash registers while men worked the floors from

99 See, e.g., Kimberly Blanton, In the Publix Eye: \$81.5 Million Settlement is a Showcase for EEOC's Activism in High-Profile Class Action Suits, BosTON GLOBE, Feb. 16, 1997, at E1 (company official quoted as saying that "many female associates do not have an active interest in stocking shelves”); Gregg Fields, Publix Settles Discrimination Case, Miami Herald, May 30, 2001, at D1 (company had attributed lack of women mangers to "career choices that women themselves made, such as reducing hours after they had children.”).

100 See EEOC v. Sears, Roebuck \& Co., 628 F. Supp. 1264 (N.D. Ill. 1986), aff'd 839 F2d 302 ( $7^{\text {th }}$ Cir. 1988). In the case involving Lucky stores, the District Court Judge catalogued the list of excuses the company offered for the lack of women in management positions: "[W]omen do not want to work late shifts, men don't want to compete with women or have a woman as their boss . . . that women do not have the drive to get ahead." Stender, 803 F. Supp. at 332.

101 The language comes from the Supreme Court's decision in the Teamsters case. See Int'l Bhd of Teamsters v. United States, 431 U.S. at 342 n.23 ("The company's inability to rebut the inference of discrimination comes not from a misuse of statistics but from the inexorable zero.”). 
which promotions arose. ${ }^{102}$

Even though it was filed nearly thirty years after the first grocery store cases were initiated, the Wal-Mart litigation was virtually identical in substance. There were two basic claims underlying the Wal-Mart litigation. The one that drew the most attention, and was likely most critical to seeking substantial damages, involved the lack of women managers throughout the company. Here the plaintiffs made simple calculations: women comprised more than $70 \%$ of the employees but only about $30 \%$ of the managers. ${ }^{103}$ On this level, there was no material difference between these basic calculations and those that were advanced in the grocery store cases and, not surprisingly, the defendants raised many of the same defenses - women lacked interest, were unwilling to relocate and were less qualified. This latter issue, the disparate qualifications of men and women was complicated because Wal-Mart lacked records for many of the managerial positions. ${ }^{104}$

But the real issue in the case, even at the class certification stage, was whether it should be possible to assert a claim of systemic discrimination based on these simple mathematical comparisons. In other words, is it still possible to attribute discrimination as the cause of observed disparities based on little more than the presence of statistically significantly fewer women in managerial roles than one might expect? Another way of raising the same issue is to ask whether the same inference of discrimination that would arise from the statistical disparities in the 1970s should be permissible some forty years later?

These are complicated questions that the parties - just as was true in the Ricci litigation -- failed to grapple with. To be sure, the Wal-Mart plaintiffs sought to explain why the statistical analysis should be seen as the product of discrimination relying on what is sometimes labeled "social framework" evidence to explain how it is that sex discrimination occurs in large organizations. ${ }^{105}$ This evidence, put forward through an expert

\footnotetext{
102 The Stender case, cited in note 100 supra, is the only published case on liability. As a general matter, if a case is certified as a class action, there is a very high probability the case will eventually settle.

103 Oddly enough, these figures only appeared in the dissenting opinion issued in the Wal-Mart case. See Wal-Mart Stores v. Dukes, 131 S.Ct. at 2563 (Ginsburg, J., dissenting) ("Women fill 70 percent of the hourly jobs in the retailer's stores but make up only 33 percent of management employees.”).

104 See Dukes v. Wal-Mart Stores, 222 F.R.D. 137, 165 (N.D. Cal. 2004) (noting the incomplete applicant data Wal-Mart provided to plaintiffs).

105 The evidence was discussed, and largely dismissed, by the majority. See 131 S.Ct. at 2553-54.
} 
declaration, described how discretionary selection systems like the one in place at Walmart often operated on stereotypical assumptions about women. ${ }^{106}$ The plaintiffs also offered additional statistical analyses but, in terms of the managerial positions, they did not offer much more than the basic statistical conclusion that women were severely underrepresented in management positions.

As noted, when the case reached the Supreme Court, the question was whether the plaintiffs had satisfied the procedural requirements for class certification, and here there was an unusual twist that again complicated matters for the plaintiffs. Although Walmart was highly centralized in its supply chain of goods, it was remarkably decentralized in its hiring and promotion decisions. Stores were divided into regions and districts and store managers were provided with budgets to cover labor costs but could, within a limited range, determine how to structure that budget. ${ }^{107}$ In a closely divided decision, the Supreme Court ultimately concluded that the plaintiffs had failed to establish the commonality necessary to warrant class certification. ${ }^{108}$ This conclusion has led the plaintiffs to file a number of smaller class actions around the country, perhaps in a legal version of the old adage, "be careful what you ask for," although to date, it appears that the strategy has proved costly and unsuccessful. ${ }^{109}$

The Court, however, went beyond the procedural deficiencies to express deep skepticism regarding the plaintiffs' evidence of discrimination. For example, the Court criticized the plaintiff's social framework evidence because the plaintiff's expert - who had worked on several of the grocery store cases - was unable to quantify how likely discrimination was to have influenced Walmart's decisionmaking. Instead, the expert concluded that

${ }^{106}$ Id. (noting that plaintiff's expert "testified that Wal-Mart ha[d] a "strong corporate culture,” that makes it "vulnerable” to "gender bias.”). Needless to say, establishing that a system is "vulnerable" to discrimination is not, and should not be, the same as proving discrimination, just as proving that an individual is vulnerable to criminal activity should lead to a criminal conviction.

107 The Supreme Court explained: “Th[e] stores are divided into seven nationwide divisions, which in turn comprise 41 regions of 80 to 85 stores apiece. . . Pay and promotion decisions . . . are generally committed to local managers' broad discretion, which is exercised in a largely subjective manner. Local store managers may increase the wages of hourly employees (within limits) with only limited corporate oversight.” 131 S.Ct. at 2547 (citation and quotation omitted).

108 131 S.Ct. at 2555-56.

109 Following the Supreme Court decision, the attorneys for the plaintiffs have filed class action lawsuits in California, Texas, Tennessee, Wisconsin, and Florida. One district court has dismissed class certification. See Ladik v. Wal-Mart Stores, 291 F.R.D. 263 (D. Wisc. 2013) (denying class certification for lack of common questions). 
the system was "vulnerable to discrimination," but establishing a vulnerability to discrimination is a long way from proving discrimination and there was nothing especially retrogressive about the Court's conclusion on this point. ${ }^{110}$

There remained the question of the statistically significant disparities in female managers and here is where the Court subtly repudiated its past precedent. There is little question that the plaintiffs' statistical presentation easily satisfied the Court's jurisprudence from the 1970s, and was, in fact, presented in a far more sophisticated way. Recall, that in Teamsters and Hazelwood, the Supreme Court was willing to accept the statistical proof as relevant to discrimination on the merits, not just at the class certification stage. The statistical proof in Walmart was far stronger than either of those cases with statistically significant disparities that were strongly indicative of discrimination and yet the Court failed to draw an inference of discrimination and, in fact, was distinctly unimpressed by the evidentiary record. And the reason seems clear, though not without controversy - looking out on the floor at Walmart and seeing only male managers, the Court no longer saw discrimination as the most likely cause. The evidence the Court found compelling in the 1970s was now found wanting.

Like so many of these issues, the Court did not articulate either its repudiation of the past precedent or the rationale, and there is a difficult question lurking in the background that requires addressing. That question is, given the changes in our society and the indisputable decrease in discrimination over the last forty years, should discrimination today be easier or more difficult to prove? This is a question on which there has been remarkably little debate. Liberals often act as if discrimination has not receded, or that discrimination today is as pernicious as it was in the postJim Crow era, while conservatives tend to think of discrimination as having all but vanished. The truth is obviously somewhere in between.

Discrimination has declined and changed but that does make it any less disruptive to the lives of its victims. But it also seems unlikely that

110 See 131 S.Ct. at 2552 (noting that "Bielby testified that Wal-Mart has a strong corporate culture, that makes it vulnerable to gender bias.” (quotations omitted)). The natural response is to note that the case involved the issue of class certification rather than a judgment on the merits. The difficulty with this position involves the sheer cost of class action litigation as well as the rather clear evidence that most large employment discrimination cases settle after a class is certified. It is a fair and complicated question whether a court should take into account the likelihood that a case might settle in applying procedural rules but it would also seem problematic to ignore that fact. 
when we look out on a workplace and find racial or gender disparities, as we will in most workplaces, that we can conclude, without something more, that those disparities invariably arise from the discriminatory practices of the employer. In the 1970s, when there were no women or minorities in a workplace or in a particular job, it was easy to conclude that discrimination was the most likely cause - discrimination was everywhere and in the prior decade overt discrimination was lawful. Today we know that discrimination is less prevalent, which can also lead us to a greater reluctance to see discrimination as a causal factor.

Yet, and this is the issue at the heart of contemporary discrimination, there is no question that discrimination remains an entrenched feature of the workplace but it is often more difficult to identify because it is more complex in form. Different names are used to describe the complexity subtle discrimination, implicit discrimination, structural discrimination and occasionally unconscious discrimination - but what they all have in common is that they are distinctly different from what might be called firstgeneration or old-fashioned discrimination, the kind of discrimination around which much, if not most, of the existing case law developed. I will return to the difficulty of proving complex discrimination momentarily but at this point I want to emphasize how the Court has largely shed its fidelity to its former case law in response to the changing nature of discrimination. The proof offered in the Walmart litigation may have sufficed to uncover discrimination at one time, but today, the Court demands something more with the primary problem being that it does not really know, and certainly has not said, what that more is. But if the Court is to update the law - and this makes the issue different from that involved with the disparate impact theory - it will need to determine what kinds of statistical analysis can reliably document contemporary discrimination.

\section{THE COURT’S MODERN TURN}

There is nothing particularly problematic about the Court's decision to update the law, unless one views that decision as infringing upon Congress's mandate. While Congress could certainly update the law as necessary, and this might be a preferred method in the abstract, the reality is that it rarely does so and instead typically amends laws, at least in the discrimination field, in response to Court decisions. ${ }^{111}$ This suggests that

\footnotetext{
111 The two most recent substantial amending acts were both in response to restrictive Supreme Court interpretations - the now more than twenty-year old Civil Rights Act of 1991, and the more recent amendments to the Americans With Disabilities Act. See ADAAA 2008, P.L. 110-325, codified as 42 USCA $\S$ 12101, and Civil Rights Act of 1991
} 
the two branches have reached a reasonably stable equilibrium with respect to who defines the law: Congress allows the Court to shape the law until it provides too restrictive a definition at which point it provides a correction. $^{112}$ It is also possible that the correction or iterative process might proceed in the opposite direction - the Court would interpret the antidiscrimination statutes too broadly - but at least as measured by Congressional overrides this has never occurred in the employment discrimination field. ${ }^{113}$

Putting aside the institutional issue of who should update the law, we can then proceed to assess what the Court has replaced its old jurisprudence with, seeking to determine whether a new model has arisen that better fits contemporary discrimination. In making this assessment, it will be helpful to divide the Court's doctrine into the traditional categories of individual claims of discrimination and systemic claims of discrimination, typically defined as class actions alleging either intentional discrimination or based on a theory of disparate impact. From this perspective, the Court's doctrine with respect to individual claims might be considered a modest upgrade on the past jurisprudence; the changes the Court has made in the last decade include recognitions of different models of proof, including those that involve multiple actors or multiple motives that offer the potential to better capture contemporary discrimination. ${ }^{114}$ Even more important, the Court has established strong and clear guidelines for adjudicating retaliation claims. At the same time, the Court's vision with respect to systemic discrimination is deeply problematic for, while the Court has shed its past doctrine, it has failed to replace that doctrine, thus leaving a substantial void in claims that seek to uncover a pattern of discrimination. In particular, the Court seems to see discrimination primarily as fading rather than evolving and now seems to focus exclusively on individual claims of discrimination. Before exploring how the doctrine has evolved, it will be helpful to discuss how discrimination has changed over the last two decades in order to evaluate whether that doctrine conforms to that change.

discussed supra section II.B.

${ }^{112}$ For a discussion of the relationship between the Supreme Court and Congress with a particular focus on the Civil Rights Act of 1991 see Michael Selmi, supra note 51 [Wake Forest symposium piece].

113 One might contend that the Supreme Court's decision in Griggs v. Duke Power, recognizing the disparate impact cause of action was broader than Congress originally intended but the point here is that Congress has never stepped in to correct a Supreme Court decision because it was deemed as too expansive or protective of civil rights.

114 Desert Palace v. Costa, 539 U.S. 90 (2003), discussed infra section IV.B.1. 


\section{A. The Changed Nature of Discrimination.}

The premise of the prior section was that discrimination has changed both in its prevalence and in its origin. It is worth repeating that there is little question that discrimination has declined substantially since the foundational discrimination doctrine was established. To be blunt, this is not a point worth debating though just how much it has declined is often at the core of continuing disputes regarding the scope of antidiscrimination doctrine. Those who believe discrimination has become an anomaly are often skeptical of the need for a vibrant disparate impact doctrine or ready access to the class action device as a means to attack entrenched discrimination. ${ }^{115}$ Under this view discrimination became too easy to allege and to prove and the various inferences the early doctrine turned on are no longer relevant to contemporary society. This is the view that is best aligned with the recent Supreme Court doctrine where the Court has implicitly vacated the earlier inferences. ${ }^{116}$

Even if one accepts that discrimination has declined substantially there remains the question why antidiscrimination doctrine would need to change. It could be that there would simply be fewer cases because there is less discrimination or perhaps if the volume of cases did not decline more of the claims would fail. This argument, however, overlooks the fundamental nature of proving discrimination: ultimately, discrimination is a legal conclusion designed to explain observed social conditions, and it necessarily relies on drawing inferences from circumstantial evidence. If we see discrimination as having less explanatory power today, then we may be less likely to attribute certain behavior or disparities to discrimination. This might lead to more defense verdicts but it might also mean that cases that succeeded ten or fifteen years ago would now fail. In other words, the proof structures crafted when discrimination was a common cause might

115 See., e.g., Richard A. Nagareda, Class Certification in the Age of Aggregate Proof, 84 N.Y.U. L. REV. 97, 132-35 (2009) (cautioning against class certification in Wal-Mart case); Amy L. Wax, Disparate Impact Realism, 53 WM. \& MARY L. ReV. 621 (2011) (arguing for changing disparate impact standard to reflect changed social conditions).

116 This is true of the recent slate of cases that cast doubt on the continuing relevance of discrimination in shaping social and political realities. See Shelby County v. Holder, 133 S.Ct. 2612 (2013) (invalidating section five of Voting Rights Act); Parents Involved in Community Sch. v. Seattle Sch. Dist. No. 1, 551 U.S. 701 (2007); Ricci v. DeStefano, 557 U.S. 557 (2009) (invalidating employer's voluntary effort to address disparate testing results). One could add to this list a recent retaliation case where the Court declined to permit mixed-motive proof because doing so might "contribute to the filing of frivolous claims, which would siphon resources from efforts by employer, administrative agencies, and courts to combat workplace harassment." University of Texas Southwestern Med. Ctr. v. Nassar, 133 S.Ct. 2517, 2531 (2013). 
require modification, either implicitly or explicitly, to match current social conditions.

There is another view that needs to be integrated into the new proof structures, or the new inferential causal chain. This perspective emphasizes how discrimination has changed rather than how it has receded, how discrimination has become more subtle in nature, less likely to be linked to one bad actor, and because it is more subtle, it is by definition, more difficult to establish. Rather than advocating a tightening of proof standards, as we see in the perspective that concentrates on how discrimination has declined, this perspective calls for what might be defined as a loosening of standards so that subtle discrimination could be more easily uncovered.

Over the last decade, within the legal literature there has been an explosive interest in the changing nature of discrimination, with a particular focus on what is now termed implicit bias, sometimes also referred to as unconscious bias. ${ }^{117}$ This concept is not necessarily new - indeed Charles Lawrence's famous antidiscrimination article was written in 1986 and focused on what he termed "unconscious discrimination."118 The more recent focus on implicit bias differs primarily in the social psychology research that has arisen over the last two decades, whereas Charles Lawrence's article was based primarily on a Freudian theory that was not tied to experimental research. ${ }^{119}$

117 The list of legal scholars who have recently emphasized implicit or unconscious bias is lengthy, for a partial listing see Samuel R. Bagenstos, Implicit Bias, "Science," and Antidiscrimination Law, 1 HARV. L. \& POL’Y REV. 477 (2007); Katharine T. Bartlett, Making Good on Good Intentions: The Critical Role of Motivation in Reducing Implicit Workplace Discrimination, 95 VA. L. REV. 189 (2009); Katie R. Eyer, That's Not Discrimination: American Beliefs and the Limits of Anti-Discrimination Law, 96 MINN. L. REV. 1275 (2012); Melissa Hart, Subjective Decisionmaking \& Unconscious Discrimination, 56 ALA. L. REV. 741 (2005); Christine Jolls \& Cass Sunstein, The Law of Implicit Bias, 94 CALIF. L. REV. 969 (2006); Jerry Kang, Trojan Horses of Race, 118 HARV. L. REV. 1489 (2004); Jerry Kang et al., Implicit Bias in the Courtroom, 59 UCLA L. REV. 1124 (2012); Linda Hamilton Krieger \& Susan T. Fiske, Behavioral Realism in Employment Discrimination Law: Implicit Bias and Disparate Treatment, 94 CAL. L. REV. 997 (2006); Justin D. Levinson, Forgotten Racial Equality: Implicit Bias, Decisionmaking \& Misremembering, 57 DuKE L.J. 345 (2007); Patrick S. Shin, Liability for Unconscious Discrimination? A Thought Experiment in the Theory of Emp. Discrimination Law, 62 HASTINGS L.J. 67 (2010). For an excellent overview with cautionary notes see Ralph Richard Banks \& Richard Thompson Ford, (How) Does Unconscious Bias Matter? Law, Politics \& Racial Inequality, 58 EMORY L.J. 1059 (2009).

118 See Charles R. Lawrence III, The Id, the Ego, and Equal Protection: Reckoning With Unconscious Racism, 39 Stan. L. Rev. 1161 (1987).

119 Within employment discrimination scholarship, Linda Hamilton Krieger was 
The basic premise behind the concept of implicit discrimination is that individuals are often unaware of their own biases. A measurement instrument, known as the Implicit Association Test ("IAT") has been developed by social psychologists and is available over the internet for those who wish to use it, as millions of individuals have now done. ${ }^{120}$ The IAT measures rapid-response word associations, for example, a photograph of a famous African American might appear on the screen and the test taker then associates the photograph with words from a list. Based on what is now a database that exceeds several million test takers, individuals are often quicker to associate African Americans with negative words and the response times are then translated into a test score that measures implicit bias. A key aspect of the implicit bias research is that individuals who have high scores on the test frequently proclaim values that are steeped in equality and would consciously disclaim any intentional bias. ${ }^{121}$ This disconnect between test scores and expressed antidiscrimination norms is what leads researchers to proclaim that individuals are often unaware of the biases they hold.

The IAT has been widely used but has more recently come under criticism, particularly by a determined and small group of academics. ${ }^{122}$

largely responsible for moving into the social psychology literature. See Linda Hamilton Krieger, The Content of Our Categories: A Cognitive Bias Approach to Discrimination and Equal Employment Opportunity, 47 STAN. L. REV. 1161 (1995).

120 The literature on the Implicit Association Test is now extensive. For a review by the founders see Anthony G. Greenwald et al, Understanding and Using the Implicit Association Test: III. Meta-Analysis of Predictive Validity, 97 J. Personality \& Soc. Psych. 17 (2009). For additional discussions see Anthony G. Greenwald et al, Measuring Individual Differences in Implicit Cognition: The Implicit Association Test, $74 \mathrm{~J}$. Personality \& Soc. Psych. 1464 (1998); Allen R. McConnell \& Jill M. Leibold, Relations Among the Implicit Association Test, Discriminatory Behavior and Explicit Measures of Racial Attitudes, 37 J. OF EXPER. Soc. PsYCH. 435 (2001); Brian A. Zosek, Athony G. Greenwald \& Mahzarin R. Banaji, The Implicit Association Test at Age 7: A Methodological and Conceptual Review, at 264, in Social Psychology \& THE Unconscious: The Automaticity of Higher Mental Processes (2006).

${ }^{121}$ This is a frequent problem in measurements of discrimination, namely that explicit statements are inconsistent with actions, or in the case of the IAT with implicit attitudes. See, e.g., Laurie A. Rudman \& Richard D. Ashmore, Discrimination and the Implicit Association Test, 10 Group Processes InTERgroup Relations 359 (2007) (in two studies the IAT predicted behaviors after controlling for explicit behavior).

${ }_{122}$ See, e.g., Hal R. Arkes \& Phillip E. Tetlock, Attributions of Implicit Prejudice, or Would Jess Jackson "Fail" the Implicit Association Test?, 15 PsYCHOLOGICAL INQUIRY 257 (2004) (critiquing the attribution of prejudice); Hal Blanton et al., Strong Claims and Weak Evidence: Reassessing the Predictive Validity of the Race IAT, 94 J. APPLIED PsYCH. 567 (2009); Gregory Mitchell \& Phillip E. Tetlock, Antidscrimination Law and the Perils 
One of the critiques of the IAT is that demonstrating implicit bias based on rapid word associations will not necessarily translate to biased actions, particularly in the workplace where most actions are based on deliberation rather than instantaneous decisions. A series of studies have recently sought to document a connection between measured implicit bias and discriminatory conduct. These studies have generally relied on college students and artificial workplace decisions - limitations that are common to experimental psychology - and the studies have identified limited but meaningful relationships between IAT scores and discriminatory conduct. $^{123}$ There are also questions about what the test is actually measuring but in terms of applying the test to questions of identifying unlawful discrimination more serious issues arise.

Accepting the test results at face value, the IAT simply provides a measure of implicit attitudes, and even if one accepts that the test can serve as a fairly reliable predictor of discriminatory conduct, no court would (or should) allow a judgment of liability based on a statistical correlation or a predictive model. The various assumptions that would go into such a determination would violate any notion of fairness or due process because liability would impermissibly turn on a proclivity to discriminate. But that does not mean the IAT has no role to play in uncovering discrimination; rather, the IAT can be quite useful in explaining the more subtle nature of discrimination for contemporary society. However, from this angle, the concept of implicit bias is not as novel as it is often assumed.

Implicit bias is closely related to earlier theories of discrimination, particularly the concept of aversive discrimination that was developed in the 1970s largely by the pioneering work of Samuel Gaertner and John Dovidio. ${ }^{124}$ Aversive racism was the label that became applied to observed behavior that was inconsistent with an individual's proclaimed social norms. The theory developed around what are known as helping studies where a person would, for example, drop a bag of groceries and wait to see if anyone came to help pick them up. ${ }^{125}$ The studies documented that

of Mindreading, 67 OHIO ST. L.J. 1023 (2006).

${ }^{123}$ See Anthony Greenwald et al., Understanding and Using the IAT Test: III. MetaAnalysis of Predictive Validity, 97 J. Personality \& Soc. Psych. 17 (2009)

124 See, e.g., Adam R. Pearson, John F. Dovidio \& Samuel L. Gaertner, The Nature of Contemporary Prejudice: Insights from Aversive Racism, 3 Social \& Personality Psych. Compass 1 (2009); John F. Dovidio \& Samuel L. Gaertner, Aversive Racism \& Selection Decisions: 1989 \& 1999, 111 Psychol. SCI. 315 (2000); Samuel L. Gaertner \& John F. Dovidio, The Aversive Form of Racism, at 61, in PreJudice, DisCriminAtion AND RACISM (S.L. Gaertner \& J. Dovidio, eds. 1986).

125 See Faye Crosby et al., Recent Unobtrusive Studies of Black \& White 
individuals were quicker to help members of their own race, and this was true even among individuals who espoused theories of equality. It was hypothesized that these individuals failed to internalize accepted social norms. In other words, people would say one thing and do another, much like the results suggested by the IAT. Both theories demonstrate deep lingering forms of bias that can translate into discriminatory conduct despite the expressed intent of the actors.

As may be apparent, the theories are also closely related to the concept of stereotyping; indeed, stereotyping likely explains at least some significant portion of the IAT results. ${ }^{126}$ There is an extensive literature going back decades on stereotyping and there are different forms, some more innocuous than others. ${ }^{127}$ At least in one respect, stereotyping is an overbroad group judgment applied to individuals, and today it seems to have its strongest effect as applied to gender where stereotypes abound. For example, one might correctly note that women remain primary caretakers on average and then mistakenly conclude that all women are likely to be primary caretakers. The stereotype becomes pernicious when it is applied to exclude women from various employment opportunities. One important difference with gender stereotypes is that they are less likely to be implicit in nature if by implicit we mean that the person who holds the stereotype is unaware of doing so. ${ }^{128}$ A person may be unwilling to admit fidelity to the gender stereotype but that is not the same as being unaware of its force.

Implicit bias is also sometimes equated with unconscious bias but I

Discrimination and Prejudice: A Literature Review, 87 Psychol. Bull. 546 (1980); Samuel L. Gaertner \& John F. Dovidio, The Subtlety of White Racism, Arousal and Helping Behavior, 35 J. Personality \& SOC. Psych. 691 (1977).

126 See, e.g., Corinne A. Moss-Racusin et al., Science Faculty’s Subtle Gender Biases Favor Male Students, PNAS EARLY EDITION, 2012 ("Past studies indicate people's be3havior is shaped by implicit or unintended biases stemming from repeated exposure to pervasive cultural stereotypes.”). See also, Patricia G. Devine, Implicit Prejudice and Stereotyping: How Automatic Are They? 81 J. Personality \& Soc. Psychol. 757 (2001).

${ }^{127}$ In a recent article, Professor Charles Sullivan traced the issue of stereotyping back to 1968 in terms of its appearance in cases. See Charles A. Sullivan, Tortifying Employment Discrimination, 92 Boston U. L. ReV. 1431, 1468 (2012). For some early discussions of stereotyping see Susan T. Fiske, Stereotyping, Prejudice \& Discrimination, in The HANDBOoK OF Social Psychology 357 (Daniel T. Gilbert et al. eds, $4^{\text {th }}$ ed. 1998). Shelley C. Taylor et al., Categorical \& Contextual Bases of Personal Meaning and Stereotyping, 36 J. Personality \& Soc. Psych. 778 (1978); Anne Locksley et al., Sex Stereotypes and Social Judgment, 39 J. PERSONALITY \& SOC. PSYCH. 821 (1980).

${ }^{128}$ For a recent discussion on the role of gender stereotypes and inequality see CECILIA L. Ridgeway, Framed by Gender: How Gender Inequality Persists in the Modern WORLD 145 (2011). 
believe it is important to distinguish between these two concepts, particularly as it applies to the law. One reason for this is that when we talk about the unconscious, there is an implication that the behavior at issue cannot be controlled, and if it cannot be controlled, some have suggested that it would be inappropriate to hold employers responsible for unconscious discrimination. ${ }^{129}$ Research, however, has shown that there are various ways in which implicit bias can be held in check, including by engaging in deliberate conduct that will ameliorate the influence of bias on snap judgments. ${ }^{130}$ Using the term "unconscious" also brings up the old Freudian concept and might lead to psychiatrists in court trying to uncover the deep-seated motives of employers. ${ }^{131}$ As a matter of terminology, my preference has always been to use the term "subtle discrimination," which also best ties into existing doctrine.

The real issue with the focus on implicit bias is how the law ought to adjust to our evolving understanding of discrimination. In the next section, we will see what adjustments the Supreme Court has made over the last decade, and we will also see that the Court has mostly been insensitive to the concept of implicit or subtle bias. But it is also difficult to know what implications to draw, or to determine the law should adjust. One problem with something like implicit bias is that it is omnipresent and if applied to legal cases, could mean that virtually any decision might be tinged with bias. That is obviously too broad a brush and I think it explains why most courts have not relied on the concept to infuse their decisions. ${ }^{132}$

129 See Amy L. Wax, Discrimination as Accident, 74 IND. L.J. 1129 (1999).

130 See, e.g., Russell H. Fazio \& Michael A. Olson, Implicit Measures in Social Cognition Research: Their Meaning \& Use, 54 AnN. REV. Psych. 297, 319 (2003) ("In a variety of studies, the more motivated show evidence of having 'corrected' for their automatically activated attitudes.”); Zinda Kunda \& Steven J. Spencer, When Do Stereotypes Come to Mind and When Do They Color Judgment? A Goal-Based Theoretical Framework for Stereotype Activation and Application, 129 PSYCH. BulL. 522 (2003) (prolonged contact of ten minutes or more can reduce stereotype influence); Nilanjara Dasgupta \& Anthony G. Greenwald, On the Malleability of Automatic Attitudes: Combating Automatic Prejudice With Images of Admired and Disliked Individuals, $40 \mathrm{~J}$. PERSONALITY \& SOC. PSYCH. 800 (2001) (can modify simplistic evaluations by sending frequent counterstereotype reminders).

131 Some of this might just be a reaction to the seminal article discussing unconscious discrimination that did, in fact, rely on the work of Sigmund Freud. See Charles R. Lawrence, III, The Id, the Ego, and Equal Protection: Reckoning With Unconscious Racism, 39 StAN. L. REV. 317 (1987).

${ }^{132}$ Only a handful of cases have addressed the concept of implicit bias, and generally in a summary fashion. See, e.g., Saka v. Holder, 741 F.3d 244, 249 (1 ${ }^{\text {st }}$ Cir. 2013) (summarily rejecting claim of implicit bias in an immigration case). Two cases have relied on the concept in ruling for plaintiffs. See Diaz v. Jiten Hotel, Mgt., Inc., 742 F. Supp.2d 319, 327 \& n.11 (D. Mass. 2011) (acknowledging complexity of discrimination and 
The obsessive focus on implicit discrimination has also obscured a more important aspect of contemporary discrimination. Although discrimination has become more subtle, the more important issue is that discrimination today is the product of cumulative acts that are not traceable to a single actor or event. Rather, discrimination arises from small acts of disrespect or distrust that leads to disparate opportunities or results, and is often informed by stereotypes throughout the process. ${ }^{133}$ For example, an African American enters the workplace and certain co-workers or supervisors assume that the individual is the product of affirmative action, which makes that person appear less qualified in their eyes. This may or may not be the product of implicit bias but the result is that the employee is afforded fewer opportunities in the workplace and even within those limited opportunities will perform under a cloud of suspicion. ${ }^{134}$ The employee may also be subject to biased evaluations. In this situation, the employee might react in different ways - perhaps by working harder to prove himself or he may begin to slack off under the assumption that no matter what he does, he will not succeed. If he were to slack off, it would almost certainly be noticed and result in a completion of the circle that ends with poor performance evaluations. If the individual were a woman, the stereotypes that started the process would be different but the results would likely be the same. The beginning assumption might be either that the individual was not competent because the job at issue was a "man's" job or it might be that the woman was likely to leave the workplace when she has children. In either scenario, the individual might also be subjected to

concept of implicit bias in denying defendant's motion for summary judgment); Kimble v. Wisconsin Dept. of Workforce Develop., 690 F. Supp. 2d 765, 778 (E.D. Wisc. 2010) (concluding that defendant "behaved in a manner suggesting the presence of 'implicit bias.'”). A recent case struck the proposed testimony of Anthony Greenwald, one of the founders of the IAT, in a case involving class allegations of race discrimination because the court found the testimony did not satisfy the federal evidentiary standards for expert testimony. See Jones v. National Council of Young Men’s Christian Ass'n, 2013 U.S. Dist. Lexis 129236 (N.D. Ill. 2013). In the case, the defendant proferred a report challenging the basis of the IAT by Philip Tetlock, one of the chief antagonists of the concept of implicit bias.

${ }^{133}$ For an excellent discussion of the cumulative effect of discreet acts see VIRGINIA Valian, Why So Slow? The AdVANCEMENT OF Women (1998).

${ }^{134}$ An excellent example of the complicated ways discrimination can influence an employment process is found in the story and lawsuit of Lawrence Mungin, who sued after his quest for partnership was delayed. He initially received a large jury verdict, which was overturned on appeal. See Mungin v. Katen, Muchin \& Zavis, 116 F.3d 1549 (D.C. Cir. 1997). The case itself does not fully capture both the complexity and ambiguity of discrimination. For that one has to turn to the excellent book written by Mungin's college roommate. See Paul Barrett, The Good Black: A True Story of Race in America (1999). 
harassment while on the job - taunts, or statements questioning one's competency, whatever the case may be.

The important aspect of this form of discrimination is that there is no single actor, no single event, but instead the discrimination arises as a result of the cumulative effect of a series of discrete acts. How one assesses this situation might depend on the time frame one analyzes. If one looks just at the failed promotion, it might appear that the person was justifiably denied a promotion due to poor performance evaluations or even poor performance. One would have to step farther back to understand that the person was treated in a discriminatory fashion from the beginning. But it is not an easy story to tell, and the story is only complicated by bringing the concept of implicit bias into the equation.

\section{B. The Changed Doctrine.}

\section{Individual Claims of Discrimination.}

Over the last decade, the Supreme Court has altered the doctrine relating to individual claims of discrimination in two particular ways. First, the Court has made it easier for plaintiffs to proceed under what is known as a mixed motives theory, a circumstance where an employer has multiple motives for its action, at least one of which is discriminatory. ${ }^{135}$ As discussed more fully below, this judicial innovation was primarily the product of clear statutory interpretation and has turned out to be of limited utility for most plaintiffs, despite its initial enthusiastic reception among academics. $^{136}$ More important than the expansion of the mixed-motives theory, the Supreme Court has crafted a far-reaching doctrine relating to retaliation claims, and here the evolution of the doctrine has provided employees with an important tool to protect their statutory rights and also highlights the individualized complaint-based system that defines the contemporary antidiscrimination system.

135 See Desert Palace, Inc. v. Costa, 539 U.S. 90 (2003) (allowing mixed motive cases to be based on circumstantial evidence).

136 The Supreme Court's Costa decision was initially met with a wave of enthusiasm by academics who saw in the case the potential for greater success on claims of discrimination. See, e.g., Jeffrey A. Van Detta, "Le Roi Est Mort; Vive Le Roi!": An Essay on the Quiet Demise of McDonnell Douglas and the Transformation of Every Title VII Case After Desert Palace, Inc. v. Costa Into a "Mixed Motives" Case, 52 DRAKE L. REV. 71 (2003); Michael Zimmer, The New Discrimination Law: Price Waterhouse is Dead, Whither McDonnell Douglas, 53 EMORY L. J. 887 (2004). 


\section{a. The Development of the Mixed Motives Theory.}

If one were looking for a way the Court has adapted the law to contemporary discrimination, one might look to the development of the mixed motives theory, as reflected in the Court's decision in. Desert Palace v. Costa. ${ }^{137}$ The mixed motives theory involves a circumstance where an employer has multiple motives for its decision, some of which might be legitimate while others are discriminatory in nature. ${ }^{138}$ A number of scholars have championed the mixed motives theory as best reflecting the reality of actual workplace decisions where it is unlikely that a single motive underlies a complicated employment decision. ${ }^{139}$ While it is true that the concept of a mixed motive may best describe how decisions are actually made, the Supreme Court deserves little credit for moving the law forward on this basis, and in fact, the mixed motives theory has not been particularly useful in uncovering subtle discrimination. ${ }^{140}$

The Costa decision addressed a narrow issue - whether the mixed motives theory was limited to claims that involved direct evidence. ${ }^{141}$ The notion that direct evidence was required to pursue a mixed-motives claim arose in the venerable case of Price Waterhouse v. Hopkins as a result of Justice O'Connor's limiting concurring opinion. ${ }^{142}$ In that case, Ann

137539 U.S. 90 (2003).

${ }^{138}$ The theory is not unique to Title VII and first arose in the Supreme Court in a First Amendment case involving a teacher's rights. See Mt. Healthy City Sch. Dist. V. Doyle, 429 U.S. 274 (1977). Some twenty years later, the issue resurfaced in a famous case involving the denial of a partnership of a woman in the accounting firm of Price Waterhouse, discussed infra. See Price Waterhouse v. Hopkins, 490 U.S. 228 (1989).

${ }_{139}$ The initial enthusiasm for the mixed-motives theory arose in the mid-1990s shortly after the passage of the Civil Rights Act of 1991. See Deborah C. Malamud, The Last Minuet: Disparate Treatment After Hicks, 93 MicH. L. REV. 2229, 22315-17 (1995) (critiquing single-motive theory as inconsistent with realities of modern workplace); Linda Hamilton Krieger, The Content of Our Categories: A Cognitive Bias Approach to Discrimination and Equal Employment Opportunity, 47 STAN. L. REV. 1161 (1995) (advocating greater use of mixed-motives proof model).

140 Any notion that the Supreme Court was moving the law forward via the mixed motives theory has been clearly refuted in their subsequent decisions that declined to extend the theory to other contexts. See University of Texas Southwestern Med. Ctr. v. Nassar, 133 S.Ct. 2517 (2013) (holding that the mixed motives framework does not apply to retaliation claims); Gross v. FBL Finan. Servs., Inc., 557 U.S. 167 (2009) (declining to apply mixed-motives framework to age discrimination statute).

${ }^{141} I d$. at 92 ("The question before us . . . is whether a plaintiff must present direct evidence of discrimination in order to obtain a mixed-motive instruction under Title VII . . .”).

142 Price Waterhouse v. Hopkins, 490 U.S. 228 (1989)(O’Connor, J., concurring) (advocating limiting mixed motives theory to situation where the plaintiff can "show by 
Hopkins was denied consideration for partnership in her accounting firm and the Court treated the case as involving mixed reasons, some of which might have been discriminatory and others legitimate. ${ }^{143}$ Although a plurality of the Court permitted such a claim to move forward, Justice O'Connor concluded that the mixed motives theory should only be available in cases that involved direct evidence. ${ }^{144}$ That case was later modified by the Civil Rights Act of 1991 which broadened the standard for succeeding on a mixed-motives claim from proving discrimination was "the motivating factor," to establishing that it was "a motivating factor." "145 In Costa, the Supreme Court found that the statutory change was not intended to be limited to cases involving direct evidence - which are but a small subset of cases -- but instead encompassed the far more common case that turns on circumstantial evidence. Given that the path to Costa ran through Congress, it would seem a stretch to attribute the development of the mixed motives theory to the Supreme Court, particularly since the Congressional action was prompted by what was perceived as a restrictive Court decision. $^{146}$

As noted above, the Costa decision was initially met with robust enthusiasm by academics and some courts as offering a more expansive view of discrimination. ${ }^{147}$ The very concept of a mixed-motive seemed to better capture the reality of the contemporary workplace where things are messier and less prone to identifying a single motive for any decision. Relatedly, the move from having to prove that discrimination was "the motivating factor" to "a motivating factor" should have opened up many circumstances to a finding of discrimination, particularly once the direct evidence limitation was discarded. And initially, several courts incorporated the theory into their summary judgment standards, making it, at least on the surface, harder for employers to obtain summary judgment

direct evidence that an illegitimate criterion was a substantial factor in the decision.”).

143 Id. at 456.

144 Id.

14542 U.S.C. § 2000e-2(m).

146 This always struck me as an odd interpretation of the Price Waterhouse case if for no other reason than the plurality decision, which was altered by the 1991 Act, was written by Justice Brennan. Yet, regardless of how one characterizes the decision, there is little question that the statutory change significantly broadened the scope of the mixed motives theory.

147 See William R. Corbett, An Allegory of the Cave and Desert Palace, 41 Hous. L. REV. 1549, 1551 (2005) (claiming that "McDonnell Douglas, divested of any procedural significance after Desert Palace, no longer seves the purpose it served during its first thirtyone years.”); Michael J. Zimmer, The New Discrimination Law: Price Waterhouse is Dead, Whither McDonnell Douglas? 53 EMORY L.J. 1887, 1948 (2004) (claiming that McDonnell Douglas should only apply to a small subset of cases). 
since employees only needed to present sufficient evidence to demonstrate that discrimination played a motivating role in the decision. ${ }^{148}$

Ultimately, however, the initial enthusiasm was not matched by the practicing bar, and for reasons that should have been fairly predictable. Although the mixed-motives theory makes it easier for a plaintiff to establish discrimination, the defendant - and this goes back to the early 1970 s -- is afforded an opportunity to prove that it would have made the same decision absent the discriminatory motive. After the 1991 Act, a plaintiff is entitled to a judgment of liability after proving that discrimination was a motivating factor, but if the defendant succeeds in establishing it would have made the same decision anyway, the remedies are limited to injunctive relief and attorney's fees. ${ }^{149}$ In that situation, the employee wins only to the extent it recovers its attorney's fees, generally not the primary goal of most litigants. The mixed-motives theory thus provides limited appeal as a trial strategy for most plaintiffs and has had very little influence on expanding the definition of discrimination. In particular, the theory has not turned out to be a more effective means of uncovering subtle discrimination, and most of the cases that have been pursued under the mixed motives framework have resembled traditional cases. Indeed, the theory largely fits within the restrictive model the Court has developed - it is premised entirely on individual claims of discrimination, and as a theory, provides only limited remedies to plaintiffs.

\section{b. Retaliation Claims.}

If the mixed-motives theory has proved of limited value, the invigorated retaliation cause of action has unquestionably offered enhanced protections for those who oppose discriminatory practices. This has been one of the most interesting developments within antidiscrimination law over the last two decades. In a series of cases, many of which were textually problematic, the Supreme Court has strengthened the protections for individuals who complain about discrimination and those cases have sparked a torrent of retaliation claims. For nearly a decade, retaliation claims have been the fastest growing of the antidiscrimination claims filed with the Equal Employment Opportunity Commission ("EEOC"). ${ }^{150}$ Yet,

${ }^{148}$ See, e.g., Roberson v. Alltel Info Servs., 373 F.3d 647 (5 $5^{\text {th }}$ Cir. 2004); Dunbar v. Pepsi-Cola General Bottlers of Iowa, Inc., 285 F. Supp. 2d 1180 (N.D. Iowa 2003). The Sixth Circuit has summarized the various approaches courts initially adopted. See White v. Baxter Healthcare Corp., 533 F.3d 381 (6 ${ }^{\text {th }}$ Cir. 2008), cert. denied, 556 U.S. 1235 (2009).

14942 U.S.C. § 2000e-5(g).

${ }^{150}$ Between Fiscal Year 1997 and Fiscal Year 2012, the number of retaliation claims 
there is also a cautionary note within the case law development -- although at first glance, the cases might appear surprisingly protective of the rights of plaintiffs, they are, in fact, consistent with the vision that animates the Court's recent doctrine, one that is steeped in individual claims of discrimination and, equally important, individual responsibility.

The concept of retaliation has always been present in the various antidiscrimination statutes but, as a cause of action, the issue remained largely dormant until the last decade. The new interest in retaliation emerged in a curious case that found its way into the Supreme Court. In Burlington Northern \& Santa Fe Ry. v. White, the plaintiff alleged that she had suffered retaliation in the form of a reassignment and suspension without pay after she complained about her working conditions. ${ }^{151}$ The lost pay was eventually provided when she was reinstated and the reassignment involved duties that fell within her original job description. ${ }^{152}$ As the case reached the Supreme Court, the question was what the proper standard should be to assess whether someone is the victim of actionable retaliation. Unlike some substantive actions, retaliation can be meted out in various subtle ways, from office shunning to less desirable surroundings such as office space, and the Court had to determine what actions could give rise to a claim under Title VII's retaliation provision. Lower courts had been split on this issue - some circuits had adopted restrictive standards that largely paralleled Title VII's substantive antidiscrimination standard while several circuits had adopted a more liberal standard that focused on the purpose behind retaliatory acts, which are generally designed to punish and deter employees from complaining. ${ }^{153}$

The curious part of the case was that the plaintiff had prevailed in the lower courts under the most restrictive standard, thus potentially rendering the case a rather poor vehicle for assessing the merits or the need for a more liberal standard. Under those circumstances, one might have expected the Supreme Court to dismiss the case as improvidently granted but, on the contrary and in a clear sign of what was to come, the Court adopted a significantly more generous and flexible legal standard, namely that an employee could prevail on a retaliation claim by demonstrating that

filed with the EEOC have doubled, increasing from 18,198 to 37,836 and increasing from $22 \%$ of the total charges to $38 \%$. No other tracked claim has increased as fast or nearly as fast. The statistics are available at eeoc.gov/eeoc/statistics/enforcement/charges.cfm.

151548 U.S. 53 (2006).

152 Id. at $70-71$.

153 The Supreme Court discussed the various standards, the more restrictive of which required the employee to establish that a decision was "materially adverse" or an "ultimate employment decision," Id. at 68-69. 
the employer's action might deter others from filing claims. ${ }^{154}$ This standard can capture many, though not all, of the various acts thrown at individuals who file complaints, or raise concerns about their working conditions and is generally quite protective of employee interests. Indeed, in its opinion the Court specifically mentioned the possibility that scheduling changes or the absence of invitations to lunch could constitute retaliatory acts. ${ }^{155}$ Even though Ms. White's loss of income was restored when she was reinstated, the Court noted the hardship that attended the loss of income she suffered for more than a month. ${ }^{156}$ This was, by any standard, a remarkable decision that was highly protective of the employee's interests.

From there, the Court has unleashed an impressive and unprecedented string of decisions expanding the scope of antidiscrimination retaliation provisions while extending those protections to other statutes. For example, under the Fair Labor Standards Act, a statute that has generated an enormous amount of litigation in recent years, the Court held that oral complaints can form the basis of a retaliation complaint. ${ }^{157}$ The Court also held that retaliation claims could be premised on an employer's internal investigation, ${ }^{158}$ and in perhaps the most revealing decision the Court read into the federal sector Age Discrimination in Employment Act (“ADEA") a retaliation provision that was clearly not there. ${ }^{159}$ Retaliaton provisions are extremely common in antidiscrimination statutes but the typical provision was missing from the federal ADEA, and yet, the Court construed the language to include antiretaliation protections in order to make it consistent with other statutes. ${ }^{160}$ This was likely a pragmatic decision - there was little question that had the Supreme Court failed to interpret the statute to encompass retaliation claims, Congress would have amended the statute and done so quickly. But soon thereafter the Court read the filing provisions restrictively in the Ledbetter case leaving it to Congress to issue a statutory fix, suggesting that there was something

154 The standard the Court adopted required an employee to demonstrate that an employer's action "might have dissuaded a reasonable employee from making or supporting a charge of discrimination.” Id. at 68-69 (quotations omitted).

${ }^{155}$ Id. at 69. I should be clear that the Supreme Court did not hold that such acts were always retaliatory but that "context matter[ed" and such acts could be the type that would deter individuals from proceeding with claims. Id.

156 Id.

157 See Kasten v. Saint-Gobain Performance Plastics Corp., 113 S.Ct. 1325 (2011).

158 Crawford v. Metropolitan Govt. of Nashville, 555 U.S. 271 (2009).

159 See Gomez-Perez v. Potter, 553 U.S. 474 (2008).

160 The Court based its decision on an earlier case that interpreted Title IX to include a retaliation provision. See Jackson v. Birmingham Bd. of Educ. 544 U.S. 167 (2005). 
distinctive about retaliation claims. The Court has also read a retaliation provision into a Civil-War era statute, and approved of so-called third party claims in the case of an individual who alleged he was retaliated against after his fiancé filed a sex discrimination claim. ${ }^{161}$

This streak of plaintiff victories might portend an emerging concern for the rights of employees but, in the context of all of the various decisions, a different interpretation might better explain the doctrinal development. The purpose behind retaliation provisions is to ensure that employees can avail themselves of the protections Congress has afforded; the provisions, in other words, are designed to protect the statute as much, or more than, the individuals who are filing clams. ${ }^{162}$ If an employer were free to intimidate or terminate workers for taking advantage of statutory protections, those protections would largely become meaningless for the vast majority of employees - former employees, on the other hand, would likely still be willing to pursue claims since they would have no fear of workplace repercussions. But the message behind the strong protection against retaliation is that employees must file complaints, and must do so in a timely manner. In other words, employees are responsible for bringing the complaints to their employer's attention and they will have no excuse if they fail to do so since the Court has made it clear that it will protect those who file complaints.

This emphasis on filing complaints has had its greatest effect - and it might be said come home to roost -- in the area of sexual harassment law where the Court crafted an affirmative defense for employers when no tangible workplace action was taken against the employee. ${ }^{163}$ There are two elements to the affirmative defense, which is designed to afford employers an opportunity to address workplace harassment, and one of those elements requires employees to file claims in a timely fashion with some possibility of explaining why they failed to take advantage of an employer's sexual harassment policy. ${ }^{164}$ It is this latter area that courts, particularly lower

161 See CBOCs v. Humphries, 553 U.S. 442 (2008) (holding that 42 U.S.C. § 1981 encompasses retaliation); Thompson v. North American Stainless, 131 S.Ct. 863 (2010) (permitting third-party claims).

162 This is what Professor Richard Moberly has dubbed "the antiretaliation principle." Richard Moberly, The Supreme Court's Antiretaliation Principle, 61 CASE WESTERn RES. L. REV. 375 (2010). For a thoughtful and influential discussion of the concept of retaliation see Deborah L. Brake, Retaliation, 90 MinN. L. REV. 18 (2005).

163 There were two cases decided on the same day in slightly different ways. See Burlington Industries v. Ellerth, 524 U.S. 742 (1998); Faragher v. City of Boca Raton, 524 U.S. 775 (1998).

164 See Burlington Industries, 524 U.S. at 764-65 (establishing elements of affirmative 
courts, have enforced strictly, effectively requiring employees to file complaints or lose their right to proceed on the claim at all. ${ }^{165}$

Retaliation claims are also quintessentially individual claims, the right runs to the individual who registers a complaint. This would be true even when an individual filed a claim that included class allegations, unless the employer then took retaliatory actions against all class members or potential class members but even then the rights at issue would be those of individual class members. There is no concept of a retaliation claim that applies generically to a class.

Nor do retaliation claims raise issues relating to subtle or implicit discrimination. One of the reasons retaliation claims are on the rise, and have relatively high success rates, is that the claims tend to be overt in nature, hardly ever subtle. Retaliation claims often turn on timing - an individual files a complaint and she is promptly fired, or sent to an inferior job. Indeed, many courts draw inferences based solely on the timing of the retaliatory acts. ${ }^{166}$ It also makes little sense to describe retaliatory acts as indirect; those with retaliation on their mind execute their acts deliberately and directly.

\section{c. The Issue of Comparators.}

If the focus is on the doctrine created by the Supreme Court, the two areas noted above - mixed motives and retaliation claims - constitute the areas that might be considered doctrinal innovations that are designed to address discrimination in the contemporary world, although it should now be clear that neither area is designed to address the more subtle or complex forms of discrimination that influence employment decisions. Indeed, one of the lasting legacies of the early doctrine is that individual claims of discrimination continue to be proved through a process of identifying similarly situated employees who were treated differently. This established

defense).

165 For a recent article discussing the way in which lower courts have interpreted the affirmative defense see Zev J. Eigen, Nicholas Menillo \& David Sherwyn, When Rules Are Made to Be Broken, Northwestern Public Law Research paper No. 13-04, available at papers.ssrn.com/s013/papers.cfm?abstract_id=2225978.

166 See. e.g., Jones v. Bernanke, 557 F.3d 670, 677 (D.C. Cir. 2009) (noting that "temporal proximity between protected EEOC activity and adverse action can support an inference of causation when the two events are very close in time”). The Supreme Court has cautioned that actions within three or four months will usually not be sufficient to raise a causal question based on "mere temporal proximity." Clark County Sch. Dist. v. Breeden, 532 U.S. 268, 274 (2001). 
method is imperfect to be sure as it often is difficult to identify any comparators, and some courts apply extremely strict definitions of comparably situated employees which often will lead to a failure of an individual's claim because there will be no admissible comparison. ${ }^{167}$ At the same time, this method of proof comports with common conceptions of discrimination and the concept of discriminatory treatment - someone is treated differently because of a protected category and the way we know that is by identifying someone who is similar in all ways but the protected characteristic and demonstrating they were not treated the same. There is also, it should be emphasized, nothing about this method of proof that would exclude evidence of subtle or complex discrimination since such evidence would be relevant to proving differential treatment so long as one is willing to identify discrimination amid the complexity of the underlying case. That is, in the end, the real issue - convincing courts and employers that discrimination underlies the way someone is treated, and the method of comparison can adequately serve that purpose. In other words, the problem is not with the doctrine but with the limited vision of discrimination many courts, including the Supreme Court, and jurors bring to the claims. ${ }^{168}$

The complicating factor in proving discrimination is that it is necessary to draw inferences from ambiguous evidence. Those who see discrimination as playing a minimal role in contemporary society - as being the province of a few bad apples so to speak - are unlikely to see discrimination among the ambiguity, and will instead look for clear evidence of discrimination, evidence that is not likely to be present. The turn to implicit bias was designed to address some of these limitations but using the IAT as the vehicle to illustrate the presence of subtle discrimination has turned out to be a misstep because it provides a presumption of discrimination that is difficult to overcome. To give one example - if one is asked, in the context of the IAT, how one knows that discrimination provides the causal explanation for an observed behavior the answer is likely to be that we know that decisionmakers harbor implicit biases that they are unaware of. In light of that kind of explanation, there is little one can do or say, and that is the problem the IAT has introduced. In contrast, a richer fuller explanation of the complexities of modern

167 For a detailed critique see Suzanne B. Goldberg, Discrimination by Comparison, 120 YALE L.J. 728 (2011).

168 The problem is not unique to courts. Professor Samuel Sommers and his co-author have performed a series of jury studies that have led them to conclude: "[W]hen laypeople think about white racism, they tend to focus on overt, old-fashioned forms." Samuel R. Sommers \& Michael I. Norton, Lay Theories About White Racists: What Constitutes Racism (and What Doesn't), 9 GROuP Processes \& INTERGROUP RELATIONS 117, 131 (2006). 
discrimination might offer a bridge to those who are reluctant to see discrimination other than in its most blatant forms.

\section{Systemic Claims}

If the Supreme Court has reinforced the individual system of claim adjudication, it has primarily dismantled the systemic discrimination edifice. By rejecting the statistical proof offered in the Wal-Mart case, and treating the City's actions in Ricci as a form of intentional discrimination, the Court has largely turned its back on these systemic discrimination claims, and, at present, it is unclear what kind of proof the Supreme Court might accept as indicative of discrimination. It is certainly possible that it would be open to a straightforward disparate impact claim but as I have noted previously, those claims are both rare and increasingly difficult to establish because courts are willing to accept most employer justifications for the disparate impact. ${ }^{169}$

There is also a deep irony in the Court's current approach to claims of systemic discrimination. One of the issues that plagued the Walmart litigation was that there was no identifiable policy or practice that one could point to as the source of the discrimination. ${ }^{170}$ This is certainly not surprising, and the Court's reference to a policy of non-discrimination is likewise wholly unsurprising and arguably entirely disingenuous since every company now has a policy of nondiscrimination and has for many years. The irony, however, comes in that if there had been a formal policy, say one that requires prior experience as a manager that was causing the observed disparities that policy would most likely be challenged under the disparate impact theory, unless there was evidence that the policy was implemented with a specific intent to favor men. Given the Court's lengthy assault on the disparate impact theory, it would be highly ironic if systemic discrimination could only now be challenged under that theory.

From the Court's recent decisions, particularly in Ricci and WalMart, it is not at all clear what evidence the Supreme Court would accept to demonstrate a pattern of systemic discrimination. One of the more

169 See Michael Selmi, Was the Disparate Impact Theory a Mistake? 53 UCLA L. REV. 701 (2006). The number of new disparate impact cases - at least those that are litigated, continue to decline, and many of the cases involve claims that arose many years before. See, e.g., Lewis v. City of Chicago, 702 F.3d 958 ( $7^{\text {th }}$ Cir. 2012) (rejecting intervention effort in a case pending for fourteen years); Cleveland Firefighters v. City of Cleveland, 669 F.3d 737 ( $6^{\text {th }}$ Cir. 2011) (dissolving consent decree in thirty-year case).

170 See Wal-Mart, 131 at 2553. 
disturbing aspects of those cases is that in neither case did the Court majority even acknowledge the presence of discrimination, or the lengthy history of discrimination that had plagued the New Haven fire department. On the contrary, the Court seems to accept that the disparate results were the product of legitimate nondiscriminatory forces, such as hard work in Ricci $^{171}$ and a general pattern reflecting interests and abilities in the WalMart case. ${ }^{172}$ A similar sentiment ran through the Court's recent decisions involving school integration efforts where again, the Court seemed blind to the role that discrimination had played in establishing the housing patterns the school districts were seeking to address. ${ }^{173}$ It may be the case that the Supreme Court is incapable of seeing discrimination other than in its most blatant forms, where, for example, an employer has a specific discriminatory policy in place.

Again, the irony in the Court's position should be apparent: they can see discrimination only in its most blatant forms but everything we know about discrimination suggests that contemporary discrimination looks very different. Certainly it cannot be the case that an unambiguous discriminatory policy is necessary to establish a pattern of discrimination those cases thankfully are no longer common but they are also the easiest kind of claim to prevail on, and surely Title VII is not designed to uproot

171 This is reflected in the Court's conclusion that, "There is no genuine dispute that the examinations were job related and consistent with business necessity, ” even though there was no evidence on that issue at all. Ricci, 557 U.S. at 558 The Court also discussed the "high, and justified, expectations of the candidates," adding, "Many of the candidates had studied for months, at considerable and personal expense, and thus the injury caused by the City's reliance on raw racial statistics at the end of the process was all the more severe.” Id. at 594. Presumably this sentiment applied to all applicants, not just the white applicants, and all of the applicants had a reasonable expectation that the test would satisfy legal standards, including that it would be job related.

${ }^{172}$ In the Wal-Mart case, the Court emphasized that the company had a "policy" that "forbids discrimination," that was enforced by "penalties for denials of equal employment opportunity.” 131 S.Ct. at 2553 This is so obviously irrelevant - every company in the country has such policies - that it suggests the Court was going out of its way to avoid seeing discrimination. The Court was also entirely dismissive of the testimony of William Bielby, noting that it "doubt[ed]" whether it would satisfy the standards for admitting evidence by an expert. Id. at 2554. Finally, the Court noted that allowing supervisor discretion was a "presumptively reasonable way of doing business." Id.

173 See Parents Involved in Community Schools v. Seattle Sch. Dist. 551 U.S. 701 (2007). For a discussion of the Court's blindness to the role discrimination played in housing patterns see James E. Ryan, The Supreme Court and Voluntary Integration, 121 HARV. L. REV. 131, 140-41 (2007) ("But every level of government - local, state, and federal - has also played an integral and underappreciated role in fostering residential segregation by race and there has never been a concerted effort by courts or legislatures to remedy housing discrimination.”). 
only the most obvious or plain examples of discrimination. Indeed, in the venerable case of McDonnell Douglas v. Green the Supreme Court affirmed the importance of eradicating what it called "subtle" discrimination. $^{174}$

At the same time, it seems clear that the old statistical models of proof developed in the 1970s are no longer sufficient to prove discrimination. Those models primarily relied on statistical imbalances in the workforce as proof of discrimination (not just evidence but proof) and the inferences courts were apt to draw in the era that immediately followed decades of intentional discrimination no longer seem appropriate. One of the issues that ought to be addressed is the basic question why statistics should constitute proof of an intent to discriminate? I suspect that, even today, the most common response to that question might be because the Supreme Court said they could, which while true is an incomplete and unsatisfactory answer today. In the 1970s, the answer was fairly clear: stark disparities in the workforce, along with the presence of widespread discrimination, suggested that employers continued in their discriminatory ways despite the passage of the Civil Rights Act. Today that answer no longer resonates and there is little question that the inferences one can draw from statistical workforce imbalances are now diminished.

This is not to suggest that statistics are no longer relevant to proving systemic discrimination; on the contrary, statistics will always be an integral part of the proof, that is, after all how a pattern is demonstrated. In employment discrimination claims and elsewhere, statistics reveal patterns that would not be apparent if the decisions were viewed in isolation. These statistics, however, are no longer sufficient on their own, other than in the rare case when the statistical proof is so strong to leave no real doubt but that discrimination caused the disparities. Of course, such definitive proof will only be present in the very strongest claims, leaving out the more difficult or subtle cases. In any event, these two circumstances simply represent the poles on the discrimination scale - a clear discriminatory policy on the one hand and proof of a statistical imbalance on the other, and neither substantially advances our understanding of what the Court is likely to accept as proof of discrimination.

Building on the Wal-Mart decision, it also seems clear that the argument that discretion invested in supervisors invariably leads to discrimination no longer holds true, and in fact, it has not been a viable

\footnotetext{
174411 U.S. 792, 801 (1973) (“[I]t is abundantly clear that Title VII tolerates no racial discrimination, subtle or otherwise.”).
} 
argument for many years. ${ }^{175}$ At one time, several lower courts identified discretion as a primary vehicle for discrimination and were willing to draw a strong inference of discrimination solely based on discretion. ${ }^{176}$ Today, this is simply not plausible. Discretion is part of most private, and to a lesser extent public, employment systems and it would be a serious constraint if an employer could be held liable simply for relying on a system that might lead to discrimination.

The notion that discretion is not automatically associated with discrimination is also consistent with the idea that discrimination has receded. Identifying discretion with discrimination makes sense only if we assume that most or many individuals harbor discriminatory impulses but that assumption, again, seems misplaced today. Indeed, this again highlights one of the central problems with relying on the IAT to establish the pervasive influence of discrimination. If we all harbor biases that we are neither aware of nor can control, we might be apt to see discrimination everywhere we look, and a system that is "vulnerable" to discrimination because of the presence of discretion, will likely be treated as, in fact, discriminatory. That is a leap, however, that a contemporary court is unlikely to make, and I would suggest, should not make. It simply seems implausible to suggest that discrimination explains all statistical workplace imbalances, or even all disparities that we observe. At best, the IAT demonstrates that many individuals have a proclivity towards making discriminatory snap judgments but that is a long way from showing that those individuals did make snap discriminatory judgments in a particular circumstance, just as there is a substantial gulf between identifying a system as vulnerable to discrimination and one that is discriminatory. What is needed, instead, is a narrative that ties an employer's actual practices to a pattern of discrimination.

As a practical matter, this will lead to cases in which the employer either has a demonstrated history of discrimination - much like in the early days of Title VII - or there is clear evidence of a culture of discrimination. This was true in the series of cases involving the securities industry where

175 The Supreme Court said as much in the mid-1980s. See Watson v. Fort Worth Bank \& Trust, 487 U.S. 977, 990 (1988) (“It is true, to be sure, that an employer's policy of leaving promotion decisions to unchecked discretion of lower level supervisors should itself raise no inference of discriminatory conduct.”).

176 See, e.g., Bell v. Bolger, 708 F.2d 1312, 1319-20 (8 $8^{\text {th }}$ Cir. 1983) ("subjective promotion procedures are to be closely scrutinized because of their susceptibility to discriminatory abuse”); Bauer v. Bailar, 647 F.2d 1037, 1046 (10 ${ }^{\text {th }}$ Cir. 1981) (concluding that although subjective decisionmaking is not discriminatory per se "obviously subjective decision making provides an opportunity for unlawful discrimination.”). 
the plaintiffs were able to demonstrate that the companies treated women differently and disparagingly. ${ }^{177}$ Indeed, many of the cases involved graphic and extreme examples of sexist behavior, including the trips to strip clubs and the appearances of strippers in the office. ${ }^{178}$ These cases also involved statistical presentations but the anecdotal evidence bolstered the statistical case. The recent class action case against Novartis likewise included evidence that the company tolerated harassment by doctors on the female sales assistants, including one case of rape. ${ }^{179}$ Again, the plaintiffs presented impressive and detailed statistical analyses but the statistics did not do all of the work and there was no need to introduce evidence about a hypothetical workplace because the real workplace was replete with discrimination. These cases all offered a narrative that provided context for why the statistics represented proof of discrimination.

The downside to this emphasis on a culture of discrimination is that many cases of actual discrimination will not fit the model and thus go unremedied at least through litigation. This is undeniably unfortunate but it is also a litigation reality - litigation is a blunt tool not particularly adept at ferreting out complex or subtle claims of discrimination. The kind of discrimination that is often labeled as institutional or systemic in nature, where a discriminatory pattern arises as the result of aggregate decisions by multiple decisionmakers, may avoid liability even though, if we were to collect a group of discrimination experts, they would likely conclude that the employer's practices represent a pattern of discrimination. There will, it seems, generally be a gap between what might be defined as discrimination by those who are committed to rooting it out and what the courts will consider discrimination. The first group would likely conclude it is better to define discrimination expansively so as to ensure maximum efficacy while courts seem to move in the other direction, choosing to underdefine

177 During the 1990s, many, if not most, of the major securities firms were sued for sex discrimination. Most of the cases settled and only a few produced written opinions. See, e.g., Martens v. Smith Barney, 1998 WL 1661385 (SDNY 1998) (approving class settlement); Cremin v. Merrill Lynch Pierce Fenner \& Smith, Inc., 957 F. Supp. 1460, 1464 (N.D. Ill. 1997) (discussing assignment of clients that disadvantaged women). See also Patrick McGeehan, Wall Street Highflier to Outcast: A Woman's Story, N.Y. TiMES, Feb. 10, 2002, at C1 (describing one woman's plight and the industry's reputation for sex discrimination).

${ }^{178}$ Many of the unsavory exploits were captured in SUSAN ANTILLA, TALES FROM THE BoOM-BoOm RoOm: Women vs. WALL STREeT (2002).

${ }^{179}$ See Velez v. Novartis Pharmaceuticals, 2010 U.S. Dist. LEXIS 15125945 (SDNY 2010) (approving settlement of class claims). The case resulted in widespread publicity. See, e.g., Collean McClarty, Breathtaking Novartis Award, A Wake-up Call, BusinEsS Insurance, May 24, 2010, at 3; Duff Wilson, Novartis Bias Suit to Begin, N.Y. TimeS, April 7, 2010, at B1. 
discrimination, most likely based on a belief that discrimination no longer defines social and economic life.

Litigation, however, is just one tool available to root out systemic discrimination. The federal government can use its spending power to ensure that employers are not just hiring in a nondiscriminatory way but implementing affirmative action goals. ${ }^{180}$ This has long been a requirement under the federal contracting guidelines, though it is no understatement to suggest that the guidelines have typically been seriously neglected. ${ }^{181}$ Even so, eminent sociologist Frank Dobbin has found that those guidelines have played an important role in moving employers to diversify their workforces. ${ }^{182}$ Others have suggested carving out a safe harbor from liability for those employers who engage in meaningful efforts to address or close off discriminatory channels in their hiring or promotion processes. ${ }^{183}$ Both of these approaches can lead employers through a soft stick to take measures to address inequities in the workforce, and the credible threat of litigation can reinforce the importance of self-assessments.

Indeed, it may be that the Supreme Court has been persuaded that employers now have strong incentives to diversify their workforces, thus reducing the need for litigation to target subtle forms of discrimination. In the affirmative action cases that have recently come before the Court, the business community supported the various programs that were at issue and were generally seen as having substantial influence on the Court's decisions not to strike down the programs as unconstitutional. ${ }^{184}$ This is also

180 See Michael Selmi, Remedying Societal Discrimination Through the Spending Power, 80 N.C. L. REV. 1575 (2002) (advocating for use of the spending power to address societal discrimination)

181 Under a long-standing Executive Order, federal contractors with contracts in excess of \$50,000 have affirmative action obligations, a mandate that is enforced by the Office of Federal Contract Compliance Programs. See Executive Order11246, 3 C.F.R. $\S$ 339, and 41 C.F.R. § 60-50-1. Enforcement of the Executive Order has long been considered lax beginning with a conscious effort in the 1980s to minimize the burdens placed on contractors. See Alexandra Kalev \& Frank Dobbin, The Effects of Compliance Reviews and Lawsuits Over Time, 31 LAW \& SOCIAL INQUIRY 855 (2006) (noting that compliance reviews can be effective enforcement tool but commenting on the decline beginning in the 1980s). A recent government report was critical of the efforts of the OFFCP in terms of combating wage discrimination for women. See U.S. Government Accountability Office, Women's Earnings: Frederal Agencies Should Bette Monitor Their Performance in Enforcing Anti-Discrimination Laws, GAO Report - 08-799, at 21-28 (Aug. 2008).

182 See Frank DobBin, InVENTING EquAL OpPORTUNITY 38-39 (2009).

183 See, e.g., Melissa Hart, The Possibility of Avoiding Discrimination: Considering Compliance and Liability, 39 CONN. L. REV. 1623 (2007).

184 In the University of Michigan Law School case, the Supreme Court specifically 
consistent with the individualistic focus of the Court's doctrine discrimination is typically perpetrated by rogue actors that, if given a chance, the company will discipline or counteract. The affirmative defense that was created to address certain sexual harassment claims proceeds along these lines - the employer should have a first opportunity to remedy the situation, a defense that suggests a strong belief that it is in the interests of employers to address isolated acts of discrimination when they occur. ${ }^{185}$ Although there is no particular reason employer self-interests would be seen as a substitute for litigation, there is little question that many employers see economic benefits to a diversified workplace, including, quite likely a reduced threat of litigation. ${ }^{186}$

The other side of the systemic coin involves disparate impact claims. The traditional disparate impact claims challenging the use of written examinations have dramatically declined, and properly so. There is little reason to believe these tests are substantively discriminatory and it is also not so clear that employers today should be held responsible if the tests produce a disparate impact. Ideally, employers would move away from these written examinations given that they typically produce disparate results and are not well structured to provide valuable predictive information regarding the abilities of the test takers. Yet, administratively, when there are thousands of applicants, written tests will continue to be the most efficient means of screening out individuals, even though the predictive ability is weak. ${ }^{187}$ There will still be cases involving the use of written tests but increasingly they are likely to focus on those employers

acknowledged the importance of the military's need for diverse graduates. See Grutter v. Bollinger, 539 U.S. 306, 331 (2003) (highlighting the military's dependence on graduates of institutions of higher education for pool of talented officers). See also Angelo N. Ancheta, The School Desegregation Cases and the Uncertain Future of Racial Equality: Science an Constitutional Fact Finding in Equal Protection Analysis, 69 OніO ST. L.J. 1115, 1134-36 (2008) (discussing influence of amicus briefs in Court's decisions).

${ }^{185}$ See cases cited note _, supra.

${ }^{186}$ In a recent book, Professor John D. Skrentny, an astute observer of developments in civil rights, documents the ways employers have sought to diversify their workplaces even when such efforts might be inconsistent with governing legal principles. See JoHN D. Skrentny, After Civil Rights: Racial Realism in the NEW American WorkPlace 188 (2014). For an excellent historical look with a particular focus on public accommodations and schools see GAVIN WRIGHT, SHARING THE PRIZE: THE ECONOMICS OF THE CiVIL Rights REVOLUTION IN THE AMERICAN SOUtH (2013).

187 Even a well-constructed test like the LSAT has a correlation coefficient of .36, which roughly explains about $13 \%$ of the variance one observes in predicted grades. The correlation coefficient of the LSAT is discussed in Lisa Anthony Stillwell, Susan P. Dalessandro \& Lynda M. Reese, Predictive Validity of the LSAT: A National Summary of the 2009 and 2010 LSAT Correlation Studies (2011). 
who have a demonstrated history of indifference to the disparate test results. Such a history has been at the core of litigation that has targeted the New York City fire department's lengthy history of discriminatory tests, which the litigation has sought to treat as involving intentional discrimination. ${ }^{188}$

There has also been a modest revival of novel claims pursued under the disparate impact theory with the Equal Employment Opportunity Commission taking a leading role. These cases have challenged the use of credit scores in the employment process, the use of arrest and conviction records, and there has also been interest in challenging employers' practices that refuse to hire individuals who are currently unemployed. ${ }^{189}$ These claims all move the disparate impact theory in a different direction and raise the issue of whether these practices should be seen as discriminatory or require justification. Should, for example, an employer be required to justify the use of credit scores or is that an issue that employers should be free to use regardless of the effect on protected groups? Should an

${ }^{188}$ In a lengthy and contentious litigation brought originally by the Bush Justice Department the City of New York has been found liable for the use of discriminatory written tests in the fire department. See United States v. City of New York, 637 F. Supp. 2d 77 (E.D. N.Y. 2009). In a subsequent decision the court held the City liable for intentional discrimination concluding, “T]he City's use of written exams with discriminatory impacts and little relation to the job of firefighter was not a one-time mistake or the product of benign neglect. It was part of a pattern, practice, and policy of intentional discrimination against black applicants that has deep historical antecedents and uniquely disabling effects.” United States v. City of New York, 683 F. Supp. 2d 225, 273 (E.D.N.Y. 2010). That decision was recently reversed and remanded for trial with reassignment to a different judge. See United States v. City of New York, 717 F.3d 72 (2d Cir. 2013).

189 To date the cases involving credit scores have been unsuccessful, in part because the difficulty of determining what the proper measure of disparate impact is, whether the focus should be on applicants or a broader labor market measure. See, e.g. EEOC v. Kaplan Higher Learning Educ. Corp., No. 1:10 CV2882, 2013 U.S. Dist. LEXIS 11722 (N.D. Ohio Jan. 28, 2013) (granting summary judgment to defendants); EEOC v. Freeman, No. RWT 09cv2573, 2013 U.S. Dist. Lexis 112368 (D. Md. 2013) (same). The EEOC has also sued BMW and Dollar General for their use of criminal convictions in the hiring process. See Press Release, EEOC Files Suit Against Two Employers for Use of Criminal Background Checks (June 11, 2013), available at http: //www/eeoc.gov/eeoc/newsroom/release/6-11-13.cfm. This is not a new issue but it has been recently revived in a poor economy where African Americans are more likely to have disabling criminal convictions, particularly for relatively minor crimes like drug possession. The leading older case is Green v. Missouri Pac. R.R., 523 F.2d 1290 (8 ${ }^{\text {th }}$ Cir. 1975), a case that invalidated a policy that prohibited hiring anyone with a conviction other than a traffic offense. The EEOC has yet to file a case challenging a policy that excludes the unemployed from eligibility to be hired but it has expressed an interest in the area. See Meeting Transcript, EEOC to Examine Treatment of Unemployed Job Seekers (Feb. 16, 2011), available at http://www.eeoc.gov/eeoc/meetings/2-16-11/transcript.cfm. 
employer who refuses to hire those who are unemployed be required to provide a meaningful justification? One distinct advantage to these questions and cases is that they require courts to consider the purpose behind the disparate impact theory rather than ritualistically replaying old debates.

Another potential area for systemic litigation would involve bringing some of the best academic research into discrimination into the courtroom. Over the last two decades, academics have conducted what are known as resume studies to test for discrimination in the labor market. One of the most famous of the studies sent out resumes to employers who had advertised open positions that were identical in substance other than the names of the applicants - some of the resumes included names that were identifiably racial while others appeared more neutral and were designed to be treated as not racial in character. The study documented that those with identifiably racial names were substantially less likely to receive calls for interviews than the resumes with neutral names. ${ }^{190}$ Similar studies have documented discrimination towards women with children, women applying for jobs in elite restaurants, and more recently among women applying for positions in academic science labs. ${ }^{191}$ A number of scholars have advocated for the use of testers, or audit studies, as a basis for workplace litigation, ${ }^{192}$ and these studies have the distinct advantage that the evidence of discrimination is clean rather than complex, though the studies are not without their critics. ${ }^{193}$ Discrimination skeptics may still be reluctant to

190 See Marianne Bertrand \& Sandhil Mullainathan, Are Emily and Greg More Employable than Lakisha and Jamal? A Field Experiment on Labor Market Discrimination, 94 AMER. ECON. REV. 991 (2004).

${ }^{191}$ Shelly J. Correll, Stephen Benard, In Paik, Getting A Job: Is There A Motherhood Penalty?, 112 AMER. J. OF SOCIOLOGY 1297 (2007) (audit study of employers found women discriminated against in job callbacks); David Neumark, Sex Discrimination in Restaurant Hiring: An Audit Study, 91 Q. J. OF ECON. 915 (1996) (finding women were discriminated against in fine dining restaurant hiring); Corinne A. Moss-Racusin et al., Science Faculty's Subtle Gender Biases Favor Male Students, PNAS Early Edition (2012), available at http://www.pnas.org/content/early/2012/09/14/1211286109.full.pdf+html (finding both male and female scientists discriminated against women students applying for lab jobs).

192 See Devah Pager, The Use of Field Experiments for Employment Discrimination: Contributions, Critiques and Directions for the Future, 609 ANNALS OF AMER. ACADEMY OF POL. \& SOC. SCIENCE 104, 114 (2007) (noting that the studies "come to the conclusion that race has large effects on employment opportunities with a black job seeker anywhere between 50 and 500 percent less likely to be considered by employers as an equally qualified white applicant.”); Michael J. Yelnosky, Filling An Enforcement Void: Using Testers to Uncover and Remedy Discrimination in Hiring for Low-Skilled Entry-Level Jobs, 26 U. MICH. J. L. REF. 403 (1993).

193 See, e.g., James Heckman, Detecting Discrimination, 12 J. OF ECON. PERSPECTIVES 
attribute discrimination in these audit studies because an inference of discrimination will still need to be drawn but they represent an innovative way to address contemporary discrimination that works in subtle ways, and they also can move the focus beyond individual actors to the company and possibly even an entire industry. Similarly, the EEOC efforts at challenging the use of credit scores, arrest and conviction records and prohibitions on hiring the unemployed bring new issues and new questions to the forefront, issues and questions that can help redefine discrimination for the next generation.

\section{CONCLUSION}

Employment discrimination law was ripe for updating and the Supreme Court was right to resist efforts to mindlessly apply the old case law to define discrimination in the contemporary workplace. We can do better but the Supreme Court can also do better by coming to terms with the way discrimination has changed, rather than concentrating on how discrimination has declined. What that will mean for the future is hard to know but what is needed is a deeper education regarding the complex ways discrimination continues to influence labor market outcomes. It is not yet time to forego litigation that is designed to uncover either systemic discrimination that is the product of many decisions and influences, nor is it time to turn a blind eye to how subtle discrimination emerges in individual cases. Implicit bias will be one part of that educational mission but it is also important to accept the limits of that concept and instead focus on what steps individuals and employers can take to keep whatever hidden biases might exist in check. It is a time to reset the doctrine by foregoing the old models of proof in favor of identifying new claims, new narratives that will better capture the complexities of modern discrimination. 